Review

\title{
Parthenolide and Its Soluble Analogues: Multitasking Compounds with Antitumor Properties
}

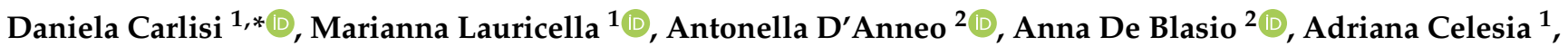 \\ Giovanni Pratelli ${ }^{1}$, Antonietta Notaro ${ }^{2}$, Giuseppe Calvaruso ${ }^{2}$, Michela Giuliano ${ }^{2}$ (I) and Sonia Emanuele ${ }^{1, *}$ \\ 1 Department of Biomedicine, Neurosciences and Advanced Diagnostics (BIND), Biochemistry Building \\ University of Palermo, 90127 Palermo, Italy; marianna.lauricella@unipa.it (M.L.); \\ adriana.celesia@unipa.it (A.C.); giovanni.pratelli@unipa.it (G.P.) \\ 2 Laboratory of Biochemistry, Department of Biological, Chemical and Pharmaceutical Sciences and \\ Technologies (STEBICEF), University of Palermo, 90127 Palermo, Italy; antonella.danneo@unipa.it (A.D.); \\ anna.deblasio@unipa.it (A.D.B.); antonietta.notaro@unipa.it (A.N.); giuseppe.calvaruso@unipa.it (G.C.); \\ michela.giuliano@unipa.it (M.G.) \\ * Correspondence: daniela.carlisi@unipa.it (D.C.); sonia.emanuele@unipa.it (S.E.)
}

check for updates

Citation: Carlisi, D.; Lauricella, M.; D'Anneo, A.; De Blasio, A.; Celesia,

A.; Pratelli, G.; Notaro, A.; Calvaruso,

G.; Giuliano, M.; Emanuele, S.

Parthenolide and Its Soluble

Analogues: Multitasking

Compounds with Antitumor

Properties. Biomedicines 2022, 10, 514.

https://doi.org/10.3390/

biomedicines10020514

Academic Editors: Agata

Grazia D'Amico, Luca Vanella and

Antonella Marino Gammazza

Received: 26 January 2022

Accepted: 19 February 2022

Published: 21 February 2022

Publisher's Note: MDPI stays neutral with regard to jurisdictional claims in published maps and institutional affiliations.

Copyright: (C) 2022 by the authors. Licensee MDPI, Basel, Switzerland. This article is an open access article distributed under the terms and conditions of the Creative Commons Attribution (CC BY) license (https:// creativecommons.org/licenses/by/ $4.0 /)$

\begin{abstract}
Due to its chemical properties and multiple molecular effects on different tumor cell types, the sesquiterpene lactone parthenolide (PN) can be considered an effective drug with significant potential in cancer therapy. PN has been shown to induce either classic apoptosis or alternative caspase-independent forms of cell death in many tumor models. The therapeutical potential of PN has been increased by chemical design and synthesis of more soluble analogues including dimethylaminoparthenolide (DMAPT). This review focuses on the molecular mechanisms of both PN and analogues action in tumor models, highlighting their effects on gene expression, signal transduction and execution of different types of cell death. Recent findings indicate that these compounds not only inhibit prosurvival transcriptional factors such as NF- $\mathrm{kB}$ and STATs but can also determine the activation of specific death pathways, increasing intracellular reactive oxygen species (ROS) production and modifications of Bcl-2 family members. An intriguing property of these compounds is its specific targeting of cancer stem cells. The unusual actions of PN and its analogues make these agents good candidates for molecular targeted cancer therapy.
\end{abstract}

Keywords: parthenolide; DMAPT; apoptosis; cell death; cancer therapy; NF-kB; oxidative stress

\section{Introduction}

Parthenolide $(\mathrm{PN})$ is a sesquiterpene lactone extracted from the medical herb feverfew (Tanacetum parthenium) that has been shown to exert both anti-inflammatory [1-3] and antitumor effects [4-6]. The biological activity of PN is correlated with its chemical structure, which includes an $\alpha$-methylene- $\gamma$-lactone ring and an epoxide (Figure 1A). These components can interact with nucleophilic sites of specific cellular proteins [7]. In particular, the unsaturated double bonds conjugated with a carbonyl group have been shown to react with free protein thiol groups, causing modulation of the redox state in the cells and induction of cell death [8].

The anti-inflammatory action of PN has been widely considered a consequence of its inhibitory effect on the transcription factors belonging to NF- $\mathrm{B}$ family [9-11]. These factors are responsible for the regulation of several diverse cellular events, including cell proliferation, differentiation and survival, and their role in inflammation is well established. NF- $k B$, upon specific stimuli, can promote the expression of proinflammatory mediators including cytokines such as TNF- $\alpha$, IL-1 and IL-6 [12], adhesion molecules (e.g., ICAM, E-selectin) and enzymes including the inducible forms of cyclooxygenase (COX-2) and nitric oxide synthase (iNOS). Therefore, they behave as a central regulator to innate immunity and inflammatory processes $[13,14]$. 


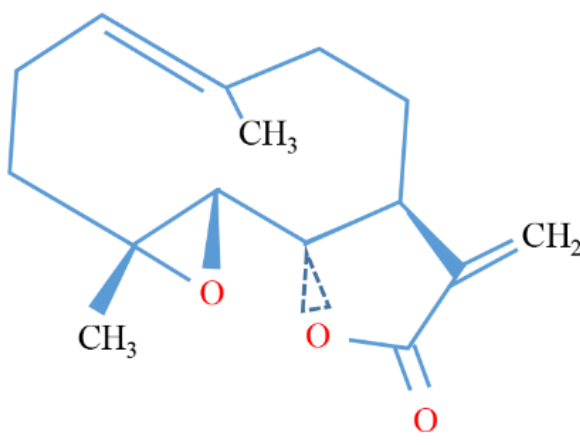

(A) Parthenolide (PN)

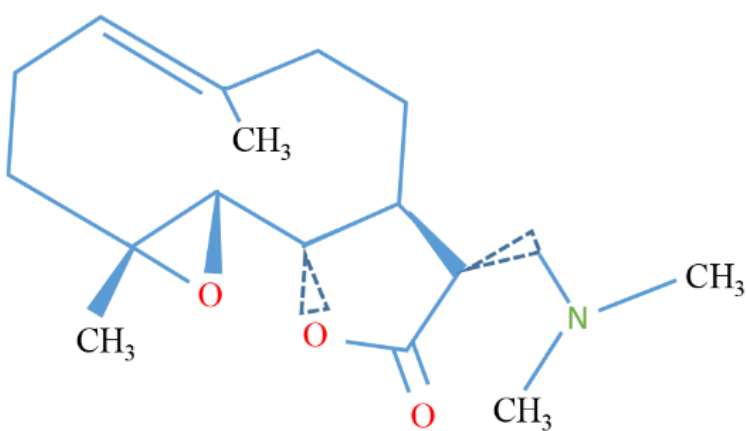

(B) Dimethylaminoparthenolide (DMAPT)

Figure 1. Chemical structures of (A) parthenolide (PN) and its analogue (B) dimethylaminoparthenolide (DMAPT).

Clinical and experimental data indicate that the NF- $\mathrm{KB}$ signaling pathway is the cause of cachexia that develops in cancer patients [15]. Indeed, patients often develop a wasting syndrome characterized by systemic inflammation and involuntary loss of body mass that cannot be reversed by normal nutritional support [15]. NF- $\kappa$ B inhibitors could also be used as anticancer therapy to treat cachexia [16,17].

As well as NF-kB inhibition, PN has been shown to directly inhibit platelet phospholipase A2, 5-lipoxygenase and inducible cyclo-oxigenase [18,19], thus contributing to inflammation prevention. In addition, evidence has been provided that $\mathrm{PN}$ can also inhibit the release of the proinflammatory mediators nitric oxide, PGE(2) and TNF- $\alpha$ from macrophages and TNF- $\alpha$, IL-2, IFN- $\gamma$ and IL- 4 from human peripheral blood mononuclear cells [1].

According to its antiphlogistic action, PN, obtained by leaves or infusions of feverfew, has been widely used in folk medical practices for treatment of fever, arthritis and migraine $[20,21]$.

In addition to its anti-inflammatory properties, PN has been shown to exert potent antitumor properties. Several recent papers highlight the role of $\mathrm{PN}$ as an antitumor agent and describe its ability to induce programmed cell death in a wide variety of tumor cell lines [22-24].

To make PN more usable in therapy, a more soluble derivative has been synthesized: dimethylaminoparthenolide (DMAPT) (Figure 1B), also known as LC-1 [25]. When formulated as a fumarate salt, DMAPT displays a solubility in water more than 1000 times greater than PN $[26,27]$.

Using the main data present in the literature to date, this comprehensive review critically summarizes the biological effects of $\mathrm{PN}$ and its analogues in tumor cells, providing an up-to-date overview of their action mechanisms and selective antitumor potential that make these naturally derived compounds promising agents for cancer therapy.

\section{The Effect of Parthenolide on Gene Expression Profile}

Both the anti-inflammatory and antitumor effects of PN have been correlated with its ability to influence the expression of specific genes through modulation of some transcription factors.

\subsection{Parthenolide and Nuclear Factor Kappa B (NF-kB)}

The factors belonging to the NF- $\mathrm{kB}$ family play an important role in the transcriptional regulation of genes involved in cell survival and immune response [14]. The most well characterized NF- $\mathrm{kB}$ components are the heterodimers constituted by p65 and p50 subunits. Activation of this complex, as well as some other NF- $k B$ dimeric forms, occurs as a prosurvival response following different proapoptotic stimuli including cytotoxic drugs [28,29], ionizing radiation $[30,31], \mathrm{TNF}-\alpha[32,33]$, oxidative stress $[34,35]$. 
In resting cells, the NF- $\mathrm{KB}$ factors are sequestered in the cytoplasm by binding to their regulatory effectors' IkB proteins. Upon specific stimulation, IkB proteins become phosphorylated on their $\mathrm{N}$-terminal serine residues. This modification targets IkB through ubiquitination and consequent degradation by the $26 \mathrm{~S}$ proteasome. NF- $\kappa B$ is thus released and can translocate to the nucleus where it promotes gene transcription [36].

The phosphorylation of IkB inhibitory proteins is controlled by specific kinases known as IkB kinases (IKK). In particular, the catalytic subunits IKK $\alpha$ and IKK $\beta$ together with the regulatory subunit NEMO, associate to form the active IKK complex (IKC) which can then phosphorylate IkB $[37,38]$.

The inhibitory action of PN on NF- $\mathrm{kB}$ has been known for many years. Several lines of evidence indicate that $\mathrm{PN}$ can exert its inhibitory action by targeting IKC components [5,39]. A direct in vitro binding of $\mathrm{PN}$ to IKK $\beta$ has been demonstrated through the alpha-methylene gamma-lactone moiety present in the molecule [40]. Moreover, Idris et al. have shown that PN prevents the activation of both IKK $\alpha$ and IKK $\beta$ and suppresses growth and migration of mammary carcinosarcoma cells [41]. Inhibition of IKK results in the accumulation of IkB inhibitory proteins with consequent sequestration of NF- $\mathrm{KB}$ in the cytoplasm.

In addition, it has been shown that PN can directly affect the translocation of the p65 NF- $\kappa B$ subunit to the nucleus $[42,43]$.

It is well known that NF- $\mathrm{kB}$ factors can promote the transcriptional activation of prosurvival/antiapoptotic genes including Bcl- $\mathrm{X}_{\mathrm{L}}$, survivin and c-FLIP [44,45]. Inhibition of NF- $K B$ by PN thus results in a reduction in the level of these gene products with consequent apoptotic effects. Many authors have recently shown that the antitumor/proapoptotic effects of PN in tumor cells are, at least in part, due to NF- $k B$ inhibition. Considering that NF- $\kappa B$ factors are involved in malignant transformation and tumor progression [46,47], the use of PN as NF- $\mathrm{kB}$ inhibitor can be particularly adequate for those tumor forms where increased activity or constitutive activation of NF- $\mathrm{KB}$ have been characterized.

Interestingly, NF- $\mathrm{kB}$ inhibition by PN has been shown to sensitize tumor cells to the effects of chemotherapeutic drugs [22,48,49] or radiation [50-53].

\subsection{Parthenolide and STAT Transcription Factors}

Other transcription factors which are targeted by PN belong to the signal transducer and activator of transcription (STAT) family. These proteins modulate a wide variety of biological processes including cell proliferation, differentiation and apoptosis as well as inflammation and immunity [54,55]. Activation of these proteins occurs following tyrosinephosphorylation by members of the Janus Kinase (JAK) family, which are cytokine receptor associated kinases. For a complete description of STAT family members and JAK signal transduction, review by Awasthi et al. and Hu et al. provide updated insights [56,57].

Phosphorylated STATs can then dimerize and translocate to the nucleus, where they exert their transcriptional activity. STATs transcriptional targets include several antiapoptotic and prosurvival factors $[58,59]$, thus indicating their oncogenic potential. In particular, among STAT family members, STAT-3 seems to play a key role in tumor transformation and malignancy $[60,61]$. Inhibition of STAT-3 in tumor cells leads to down-regulation of its transcriptional targets belonging to the Bcl-2 family including the antiapoptotic Bcl-2, $\mathrm{Bcl}-\mathrm{X}_{\mathrm{L}}$ and Mcl-1 [62]. Similar effects have been found in cutaneous T-cell lymphoma cells after treatment with a STAT-3 inhibitor [63]. Given the role of STAT proteins in contributing to cell survival, oncogenic activation of these factors, especially STAT-3, has been found in diverse types of tumors including hepatocellular carcinoma, colorectal cancer, breast cancer, bladder cancer and hematological malignancies [55,64].

Our previous studies performed in human hepatocellular carcinoma (HCC) cell lines, provided evidence that PN is able to sensitize TRAIL-induced apoptosis by reducing phosphorylated STAT-3 levels. This event appears to be related to the inhibitory effect exerted by PN on the activation of JAK proteins. Sensitization by PN to TRAIL stimulated the extrinsic mechanism of apoptosis in HCC cell lines with the activation of both caspases 8 and 3 [65]. 
PN has been shown to behave as an inhibitor of the JAK/STAT signaling pathway in response to cytokines of the IL-6 family [66]. Evidence has been provided that PN affects multiple steps of this pathway. For instance, the compound can either inhibit JAKs through binding to their SH groups, thus avoiding STAT phosphorylation [67] or directly block the DNA binding of STAT proteins in activated hepatic stellate cells [66].

In addition, recent evidence has been provided that PN can regulate crosstalk of tolllike receptor 4 (TLR4) with STAT-3, thus reducing the release of inflammatory cytokines inducing apoptosis in activated hepatic stellate cells [68].

It is interesting to note that STAT-3 inhibition by PN has also been correlated not only with apoptosis induction in tumor cells but also with reversed drug-resistance [69].

\subsection{Parthenolide Interplay with Other Transcription Factors and Epigenetic Effects}

Notably, the antitumor effect of PN has been correlated with reduced gene transcription of prosurvival mediators [70].

In this context, AP-1 is another important transcription factor which is mainly involved in cell survival and proliferation [71,72]. Interestingly, PN has been shown to inhibit AP-1 DNA binding and transcriptional activity induced by UVB in a skin cancer model, thus exerting a chemopreventive activity [73].

Microphthalmia-associated transcription factor (MITF) is strongly associated with regulation of proliferation, survival and senescence of melanoma cells [74,75]. Hartman et al. have recently provided evidence that PN efficiently decreases the MITF M isoform level in melanoma cells as a result of transcriptional regulation that results in melanoma cell senescence [73].

The Wnt/ $\beta$-catenin pathway is well known to be involved in tumor cell proliferation $[76,77]$. PN was recently shown to inhibit Wnt signaling by decreasing the levels of the transcription factors TCF4/LEF1 without affecting $\beta$-catenin stability or subcellular localization [78]. However, other authors also showed that PN is capable of reducing the levels of $\beta$-catenin in myelomonocytic leukemic U937 cells [70].

These findings might represent a nice tool to inhibit cell proliferation of those tumor types bearing $\beta$-catenin oncogenic mutations or Wnt signaling hyperactivation.

In addition to inhibition of transcription factors with prosurvival/oncogenic action, PN has been also shown to exert a function in promoting apoptosis through the activation of specific death genes. One example is given by the effect of PN on the tumor suppressor/proapoptotic transcription factor p53. It is well known that p53 is key regulator in a molecular network establishing the cell fate due to its ability to promote cell cycle arrest and/or apoptosis [79-81]. The p53 pathway is often abrogated in cancer and sometimes this might depend on increased activity of its negative regulator MDM2 [82].

In this regard, Gopal et al. have reported that PN can stimulate the ubiquitination of MDM2 thereby activating p53 cellular functions [83]. More recently, activation or stabilization of p53 by PN in tumor cells has also been found by other authors $[17,84,85]$.

However, other reports indicate that PN can also act independently of p53 [86] and promote epigenetic modifications. For instance, epigenetic modulation of the CDK inhibitor and tumor suppressor p21 by PN has been evidenced in cancer cells [87].

Through an integrated molecular profiling approach, a description of transcription factors modulated by PN was provided. PN was able to alter the binding of important transcription factors in prostate cancer including C/EBP-alpha, fos-related antigen-1 (FRA-1), HOXA-4, c-MYB, SNAIL, SP1, serum response factor (SRF), STAT3, X-box binding protein-1 (XBP1), and p53 [88]. PN interplay with some transcription factors and relative signaling is described in Figure 2. 
A



B



$\mathrm{C}$

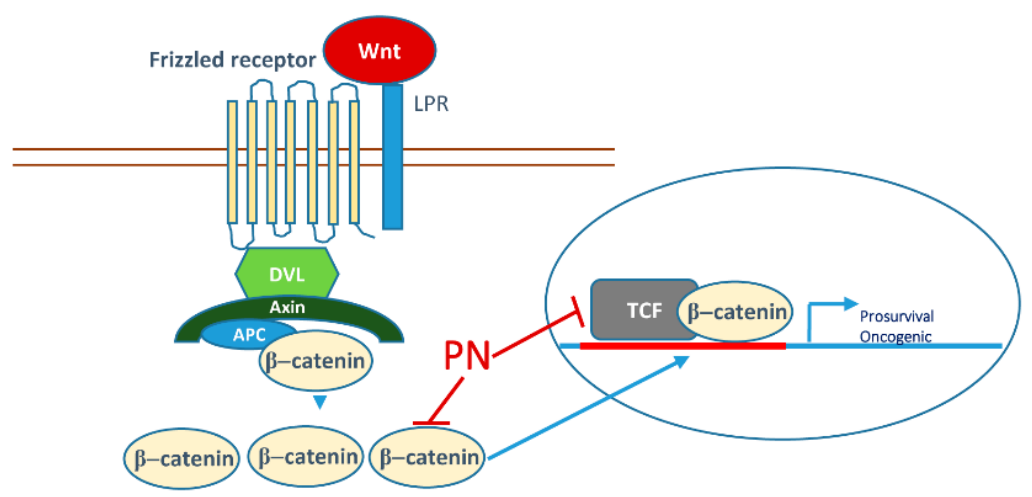

Figure 2. Effects of $\mathrm{PN}$ on prosurvival/oncogenic transcriptional factors and relative signaling: (A) NF-kB; (B) JAK/STAT; (C) $\beta$-catenin.

Beyond direct modulation of transcription factors, PN has been shown to modulate gene expression through the controls of epigenetic events. Evidence has been provided, for instance, that $\mathrm{PN}$ is able to deplete histone deacetylase 1 protein (HDAC1) and to induce cell death through ataxia telangiectasia mutated (ATM) [89]. Liu et al. have shown that PN favors DNA hypomethylation through a dual effect on DNA methyltransferase 1 (DNMT1). These authors reported that the compound can either directly inhibit DNMT1 or repress its expression by targeting transcriptional factor Sp1 binding to the DNMT1 promoter [90]. Up-to-date and wide descriptions of epigenetic effects of $\mathrm{PN}$ are provided by the papers of Irshad et al. [91] and Freund et al. [2].

\section{Parthenolide Can Specifically Modulate Signal Transduction Pathways}

A number of papers have highlighted the ability of PN to modulate signal transduction components, thereby influencing cell response to various stimuli. 
The role of PN in counteracting cytokine-mediated signaling through the inhibition of the JAK-STAT pathway has previously been noted [67]. Moreover, PN has been shown to inhibit IL-1- and TNF $\alpha$-induced NF- $\mathrm{BB}$ activation [66]. Figure 3 summarizes the effects of $\mathrm{PN}$ on different signaling cascades.



Figure 3. The effects of PN on different signaling cascades.

\subsection{Modulation of PKC and MAPKs by Parthenolide}

In addition to its effect in counteracting proinflammatory cytokine-mediated signaling, PN has been shown to exert an influence on cascades involved in cell proliferation and differentiation.

Specifically, modulation of protein kinase C (PKC) and MAP kinase components (MAPKs) by PN has been described. For instance, papers published some time ago show the effects of PN on PKC. In particular, the activation of specific PKC isoforms by PN has been shown to increase the effects of ultraviolet B (UVB) on skin cancer [92]. Moreover, evidence has indicated that PN leads to activation of the PKC and MAPK pathways, thus enhancing the differentiation of leukemia cells induced by all trans retinoic acid [93].

Considering the complex and diverse role of PKC isoforms and MAPKs in the control of cell proliferation and apoptosis, it is not surprising that contradictory data can be found regarding the effect of PN on these mediators. In contrast to the findings of the previous authors, through a protein microarray analysis of PN action in prostate cancer, Kawasaki et al. have correlated the antiproliferative effect of the compound with its ability to downregulate prosurvival kinase effectors, including PKC isoforms, MAPKs, PI3 kinase (PI3-K) and CaM kinases [94].

More recently, in line with these findings, PN has been shown to potently inhibit the B-Raf/MAPK/Erk mitogenic pathway in tumor cells [95] and to target epidermal growth factor receptor and signaling either in vitro or in vivo in lung cancer models [96]. Evidence has also indicated that PN inhibits oncogenic focal adhesion kinase in breast cancer cells [97].

Moreover, in accordance with previous considerations regarding Wnt/beta-catenin signaling, direct interference by $\mathrm{PN}$ with this oncogenic pathway was evidenced in colorectal cancer [98].

Overall, it seems that targeting prosurvival/oncogenic signaling is among the modalities that account for the antitumor action of PN. 


\subsection{Effects of Parthenolide on Stress Kinases}

The c-Jun N-terminal kinase (JNK) and the p38 kinase are members of the MAPK family that are involved in the response to cell stress and induction of apoptosis [99,100].

Many studies support a role of PN and its analogues in the activation of these kinases, an event that is often correlated with the induction of oxidative stress and the consequent execution of cell death. It has been demonstrated that the PN analogue DMAPT suppresses in vivo prostate cancer growth and induces apoptosis through reactive oxygen species (ROS) generation with subsequent JNK activation [27,43,101,102]. The same authors showed that interfering with JNK by shRNA reduces the antiproliferative and apoptotic effects of DMAPT [27]. More recently, in line with these findings, a novel PN analogue (CPPTL) displayed antineoplastic effects via the ROS/JNK pathway in acute myeloid leukemia [101]. However, other authors have previously shown that activation of JNK by $\mathrm{PN}$ can also occur independently of ROS generation and appears to be crucial to overcome resistance of breast cancer cells to TRAIL-induced apoptosis [102]. Similarly, Zhang et al. have demonstrated that PN can sensitize various human cancer cells to TNF- $\alpha$-induced apoptosis and that this effect is counteracted by JNK-dominant negative overexpression or specific JNK inhibitor [43].

It has to be considered that the role of both JNK and p38 in apoptosis is rather controversial [103-105]. In contrast to the previous findings supporting an antiapoptotic role of JNK and p38, Won et al. have provided evidence that PN inhibits the activity of both the kinases, leading to the sensitization of JB6 cells to UVB-induced apoptosis [92]. In general, the exact role of JNK and p38 in cell death varies in relationship with a number of factors that include the cell type, the kind of stimulus and the crosstalk with other signaling pathways [106].

PN has also been shown to influence the apoptotic extrinsic pathway through the modulation of the signal cascade downstream death receptors such as Apo1/Fas and TRAIL.

In this regard, Qin et al. have found that PN is capable of reversing the suppression of Fas-mediated apoptosis by TNF- $\alpha$ in acute myeloid leukemia cells, an effect which is most likely due to NF- $\mathrm{KB}$ inhibition and the consequent repression of antiapoptotic genes [107].

Evidence has indicated that PN is able to overcome resistance to TRAIL-induced apoptosis. According to the findings of Nakshatri et al. [102] PN can induce sensitization to TRAIL in resistant breast cancer, an event that is correlated with JNK activity. The apoptotic effects of PN are specifically described in the next paragraph.

\section{Parthenolide and Cell Death}

\subsection{Classic Apoptosis}

Apoptosis represents the major form of programmed cell death in multicellular organisms, and its execution is prevalently dependent on the activation of caspases [108]. Upstream events that trigger caspase-dependent cell death include receptor-mediated apoptotic extrinsic pathway and mitochondria-mediated intrinsic pathway $[109,110]$.

A number of papers have reported that PN induces apoptosis in tumor cells either stimulating the apoptotic extrinsic or intrinsic pathway (Figure 4) [111]. The involvement of caspases in PN-induced cell death has been widely documented [85]. In multiple myeloma, for instance, $\mathrm{PN}$ has been shown to be capable of inducing a rapid accumulation of cleaved products of caspase- 8 and caspase- 3 and, to a lesser extent, caspase- 9 . Consequently, PN induced caspase-dependent cleavage of the antiapoptotic factors MCL-1 and XIAP, thus promoting the execution of apoptosis [112]. However, the same authors suggested that PN cytotoxicity is likely partly caspase-dependent, as they found that pan-caspase inhibitor Z-VAD-fmk only partially protects the cells from the effect of PN. 




Figure 4. Different types of cell death induced by PN treatment.

Massive apoptosis was recently found following PN treatment in different both in vitro and in vivo tumor models [113].

Apoptotic activities of PN also account for synergistic action in combination with other antitumor compounds as described in the previous paragraph.

\subsection{Caspase Independent Cell Death}

It is widely recognized that the induction of nonapoptotic forms of programmed cell death (PCD) can represent a valid alternative when tumor cells appear to be resistant to classic apoptosis [114]. Caspase-independent PCD includes diverse forms of death that result from the activation of specific pathways and involve other proteases to trigger the terminal events that culminate in cell suicide.

The first evidence that PN could stimulate caspase-independent PCD with necroticlike morphology (Figure 4) was provided by Pozarowski et al., who found that HL-60 cells died by necrosis, concurrent with atypical apoptosis, after exposure to PN [115]. These authors showed that the different effects induced by PN depended on the concentration used. They demonstrated the presence of activated caspase- 3 in cells undergoing apoptosis after treatment with $10 \mu \mathrm{M}$ PN. On the other hand, at $30 \mu \mathrm{M}$ PN they observed that most cells did not show any evidence of caspase- 3 activation and revealed a necrotic morphology. Necrotic-like features thus appeared at higher PN concentrations, although were not identified as real necrosis.

Nevertheless, necrotic-like phenotype induced by PN was not further characterized, and necroptosis, the main caspase independent necrosis-like PCD form, has not yet been documented to be specifically activated by the compound. However, we have previously found that PN is capable of increasing the expression of RIP1, a major kinase involved in necroptosis [116].

Among caspase-independent cell death types, the type that was originally called “apoptosis-like PCD" includes apoptosis inducing factor (AIF)-mediated cell death. This factor is released by mitochondria under specific stimuli and translocates to the nucleus, where it promotes chromatin condensation and cell death. It has been documented that $\mathrm{PN}$ is able to induce cell death through an AIF-dependent mechanism in melanoma and osteosarcoma cells. In this mechanism, dissipation of the mitochondrial transmembrane potential but not the activation of the caspases has been highlighted [117].

Supporting a possible switch toward PN-induced cell death without caspase involvement is the recent observation that, under particular circumstances, PN can reduce the expression of caspase 3 and caspase 9 and is also capable of suppressing their activation [118]. 
Considering these observations as well as strict crosstalk among different types of cell death, further studies are needed to clarify the mechanisms of PN-induced Caspase independent-PCD in tumor cells.

\subsection{Autophagy}

Autophagy is a physiological process that leads to the lysosomal degradation of cellular components and damaged organelles, representing a prosurvival cellular response to various types of stress $[119,120]$. Under certain conditions, this process can evolve into a death event, namely called autophagic cell death [121]. The activation of this pathway is fundamental for tumor cells that show resistance to classical apoptosis and can, therefore, induce recurrence [122,123].

PN can induce cell death through autophagy activation (Figure 4) without the involvement of caspases. Yang et al. [24] demonstrated that in human osteosarcoma cells, PN induces human osteosarcoma cell death by activating autophagy and mitophagy. PN induction of autophagic death is associated with increased ROS and does not involve caspases.

Activation of the autophagic mechanism by PN could be an excellent strategy to enhance the action of chemotherapeutic agents [124]. It has been shown that PN induces autophagy in human promyelocytic leukemia cell line HL-60 and in human epithelial carcinoma HeLa cell line. The researchers also highlighted that the autophagic mechanism is necessary for PN to activate apoptosis [125].

In glioblastoma (GBM) cells, the efficacy of chemotherapy is limited by intrinsic resistance [126]. PN can induce survival inhibition and trigger cell death through autophagic activation in the GBM U373 cell line [127].

\section{Parthenolide and Oxidative Stress}

Targeting intracellular redox pathways can be considered as a therapeutic approach for cancer [128]. Oxidative stress is a cell condition caused by increased production of reactive oxygen species (ROS) or reduced function of antioxidant defense systems [129]. It is well known that ROS can behave as mediators of apoptosis. Unbalanced intracellular redox status can, in fact, trigger specific events including alteration of mitochondrial function and activation of death signaling pathways [130].

Many lines of evidence indicate that PN can promote apoptosis in tumor cells through the induction of oxidative stress [131,132] (Figure 5). This was first observed by Wen et al., who found that PN-induced apoptosis in hepatoma cells was accompanied with depletion of glutathione (GSH), generation of ROS, reduction of mitochondrial transmembrane potential and activation of caspases. These effects were effectively abrogated by the antioxidant N-acetyl-1-cysteine (NAC) and enhanced by the GSH synthesis inhibitor buthionine sulfoximine (BSO) confirming the role of oxidative stress in PN-induced apoptosis [133].

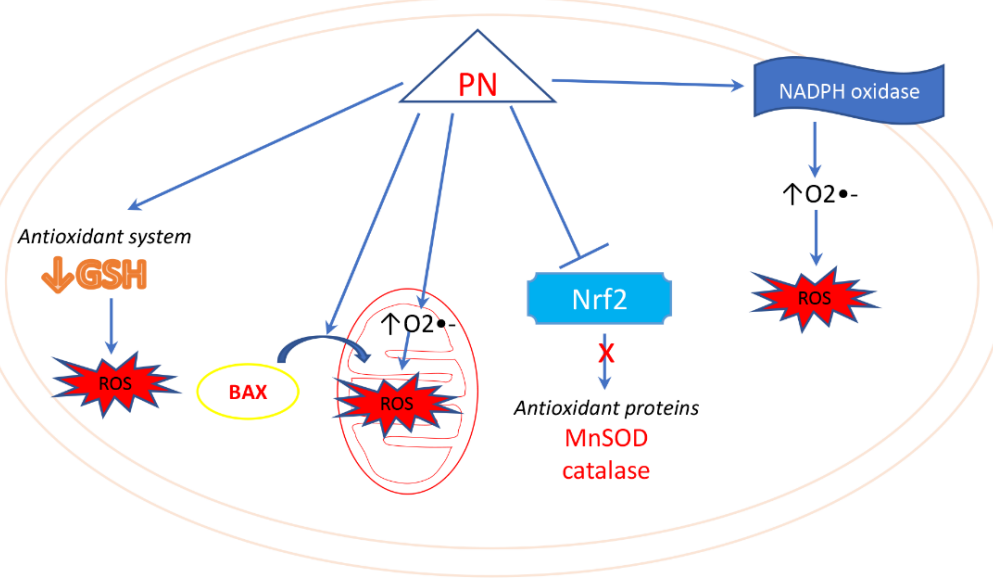

Figure 5. Mechanisms of oxidative stress induction by PN. 
The principal site of ROS production in the cell is represented by the mitochondrial respiratory chain [134]. It has been demonstrated that treatment of tumor cells with PN exerts profound effects on mitochondria through the involvement of proapoptotic members of the Bcl-2 family, such as Bid, Bax and Bak. Consequent modifications across the mitochondrial membrane, determined by the proapoptotic Bcl-2 family proteins, lead to the subsequent release of mitochondrial death effectors, including cytochrome $c$ and Samc/Diablo [135].

Kim et al. [136] have further shown that Bax translocation to the mitochondria correlates with ROS production during PN-induced apoptosis in cholangiocarcinoma cells. In particular, these authors have found that Bcl-XL-mediated inhibition of Bax translocation can decrease PN-induced ROS generation and subsequently inhibits the reduction in mitochondrial membrane potential and the release of proapoptotic factors from the mitochondria [136].

In addition, it has been reported that PN-induced apoptosis in multiple myeloma (MM) cells involves oxidative stress and that cell sensitivity depends on catalase activity [137]. Interestingly, the same authors found a different expression of catalase in MM cells than in normal lymphocytes, thus explaining the different response to PN. The compound appeared to be ineffective in normal cells that displayed a higher level of catalase [138].

Other authors have also supported the evidence that PN preferentially acts on tumor cells promoting oxidative stress rather than in normal cells [139]. They showed that PN causes oxidative stress in prostate cancer cells but not in prostate epithelial cells. This effect seems to be dependent on a selective stimulation of NADPH oxidase (NOX) by PN in tumor cells with a consequent decrease in thioredoxin reduction and downregulation of FOXO3a targets antioxidant enzyme manganese superoxide dismutase (Mn-SOD) and catalase [139].

PN and DMAPT also induced oxidative stress through activation of NOX in breast cancer cells $[116,140]$. It was highlighted that after a short treatment $(1-8 \mathrm{~h})$ with PN in MDA-MB231, there was an increase in $\mathrm{O} 2 \bullet-$ induced by the activation of NADPH oxidase. With a longer treatment time, PN also induced mitochondrial production of $\mathrm{O} 2 \bullet-$, likely blocking mitochondrial activities. The induction of oxidative stress by PN was the main cause of reduced cell viability of breast cancer cells [116,140]. Experimental evidence has suggested that NOX involvement is a consequence of PN-induced activation of the EGFR receptor [141].

According to the findings of Kurdi et al., in cardiac myocytes, PN generation of ROS can depend on either mitochondria or NADPH oxidase in relationship with the concentration of the compound used [142]. Specifically, PN generated superoxide anion, and at lower concentrations $(<5 \mu \mathrm{M})$ the source of superoxide was mainly mitochondria; at higher concentrations ( $>5 \mu \mathrm{M})$ the primary source was NADPH oxidase [142].

Although the precise mechanism of PN induced oxidative stress remains unclear, it seems that its ability to bind thiol groups can account for its effect on reduction of intracellular GSH and protein thiols, such as thioredoxin [139]. In accordance with this hypothesis, a recent report has described the role of PN in modifying extracellular protein thiol groups and identified surface thioredoxin-1 as one of the targets of PN in lymphoma cells [8]. These authors, however, did not provide a precise explanation of how altering the redox state of exofacial thiols modulates cell death and speculated that surface thioredoxin can mediate the crosstalk between exofacial thiols and downstream intracellular events [8].

A direct action of PN on intracellular thiols, including both free GSH and protein thiols, has been previously described by Zhang et al. [7]. These authors found that colorectal cancer cells underwent apoptosis following treatment with PN through depletion of intracellular thiols and concomitant increase in ROS production and intracellular calcium [7].

It is evident that PN effects on the cell redox state and mitochondrial activity are key components of its action mechanism.

Interestingly, chemoresistance often correlates with an increase in antioxidant activity and a reduction in intracellular ROS level [134,143]. In fact, many cancer cells express 
high levels of the transcription factor Nrf2, which increases the antioxidant defenses of the cells $[144,145]$. PN inhibits chemoresistance by inhibiting the overexpression of both Nrf2 and downstream targets, such as MnSOD and catalase [146]. PN likely induces Nrf2 inhibition via increased expression of miR-29b-1-5p [147], a miRNA that regulates the inhibition of proliferation and invasion of triple-negative breast cancer cells (TNBC) [148].

\section{Parthenolide Selectivity in Tumor Cells and Targeting Cancer Stem Cells}

\subsection{Selective Action of Parthenolide in Tumor Cells}

Evidence has been provided that PN can selectively induce apoptosis in tumor cells rather than in the normal counterparts $[86,112,137,139,149]$ thus displaying a high potential in cancer therapy.

In addition, in vivo studies have shown that PN is capable of suppressing tumor growth and, in some cases, preventing metastasis in different mice xenograft models including mammary carcinosarcoma [41], triple negative breast cancer [116,150], acute leukemia [26], prostate cancer [27,50,151] and renal carcinoma [152].

Interestingly, the antitumor efficacy of $\mathrm{PN}$ is also sustained by its ability to overcome cell resistance to conventional chemotherapeutic agents or other antitumor compounds.

The significant in vivo chemosensitizing properties of $\mathrm{PN}$ have been evidenced by Sweeney et al., who obtained reduction in metastasis and improved survival in a xenograft model of breast cancer following a combination treatment of PN with docetaxel [153].

Our previous studies demonstrated that PN and its soluble analogue DMAPT also have a selective effect against triple-negative breast cancer cells and not against normal cells (HMEC) [146]. Furthermore, it has been shown that the administration of DMAPT in nude mice carrying xenografts of MDA-MB231 cells results in inhibition of tumor growth, an increase in mouse survival and a reduction in the metastasis process [116].

To date, the only clinical trial based on PN administration to patients with cancer is reported by Curry et al. [154], who conducted a phase 1 trial to evaluate the pharmacokinetics and toxicity of the compound extracted by feverfew. PN was administered as a daily oral tablet in a 28-day cycle, and patients were evaluated for response after every two cycles. Based on their results, PN had no significant toxicity, but when administered in doses of up to $4 \mathrm{mg}$ it did not provide detectable plasma concentrations. This limit was attributed by the authors to the fact that they could not provide desirable levels of PN with the feverfew preparation [154].

It should be noted that PN has no toxic effect in normal cells and can protect against oxidative stress. Some studies show that PN has scavenging activity against reactive oxygen species, thus protecting myoblast cells. In particular, it has been shown that PN modulates mitophagy induced by oxidative stress and protects C2C12 myoblasts from apoptosis, suggesting a potential protective effect against skeletal muscle diseases associated with oxidative stress [17].

\subsection{Parthenolide and Cancer Stem Cells}

Many studies have shown that in some forms of cancer, there are cells with specific stem-like properties called cancer stem cells (CSCs) [155]. CSCs are considered the "initiating" cells of the tumor and the main reasons behind tumor heterogeneity, resistance to therapy and recurrence [156,157].

Therefore, a drug capable of targeting both CSCs and cancer cells would be an excellent therapeutic strategy for the treatment of cancer patients. Several studies have shown that $\mathrm{PN}$ is a compound capable of acting on CSCs.

Breast cancer is the most common form of cancer diagnosed in women worldwide and, despite the development of new diagnostic and therapeutic methods, is a leading cause of death. The presence of CSCs is potentially the cause of treatment failure; drug resistance; metastasis; and relapse after surgery, chemotherapy and radiotherapy in breast cancer.

There are several studies showing the effect of PN in reducing the presence of CSCs in solid and hematological tumors [4,158-160], acting mainly on NF-кB inhibition. 
The first studies on the cytotoxic effect of PN on CSCs focused on hematological tumors. Leukemia stem cells (LSCs) are the main cause of the onset, growth and recurrence of acute and chronic myeloid leukemia (AML and CML). PN induces apoptosis in primary human AML cells and CML cells, and in LSCs derived from AML without effect in normal hematopoietic cells. The apoptotic mechanism induced by PN is associated with the inhibition of NF- $\mathrm{kB}$, the proapoptotic activation of p53 and the increase of reactive oxygen species (ROS) [26].

Recent studies have shown that PN is able to reduce the presence of LSCs in drugresistant leukemia K562/ADM cells and increase their sensitivity to apoptosis induced by doxorubicin through the downregulation of P-gp mediated by NF- $\mathrm{B}$ [161].

The cytotoxic effect of PN has also been highlighted in multiple myeloma cancer stem cells (MM-CSCs). Multiple myeloma (MM) is an incurable malignant plasma cell tumor in which nearly all patients succumb to relapse. In vitro studies conducted using a three-dimensional tissue culture system have shown that $\mathrm{PN}$ has a potent cytotoxic effect against MM-CSCs [162].

Triple-negative breast cancers (TNBCs) are aggressive forms of breast cancer associated with a high recurrence rate. Carlisi et al. [150] found that PN and its more soluble analog DMAPT induce cytotoxic effects in CSCs of TNBC. It has been shown that both PN and DMAPT reduce the formation of mammospheres in TNBC cell lines (MDA-MB231, BT20 and MDA-MB436). In particular, the compounds exerted a significant inhibitory effect on the viability of stem cells derived from the dissociation of mammosphere, inducing the generation of ROS, mitochondrial dysfunction and cell necrosis [150].

Zhou et al. [163] have demonstrated that PN can inhibit the formation of mammospheres in MCF-7, a breast cancer line responsive to estrogen and progesterone receptors. This effect is mediated by the inhibition of NF- $\mathrm{kB}$ activity.

$\mathrm{PN}$ was found to increase the cytotoxic effect in CSCs derived from breast tumors by vinorelbine, a semisynthetic vinca alkaloid that acts through disruption of microtubule assembly. Liu et al. [164] developed liposomes containing PN and vinorelbine. Their combined cytotoxic effect was evaluated in MCF-7 and MDA-MB-231 cells and in CSCs derived from them. The antitumor activity of the combined treatment of liposomes containing vinorelbine and PN was also evaluated on MCF-7 xenografts [164].

It is known that the 5-fluorouracil (5-FU) chemotherapeutic agent has a powerful cytotoxic effect on most cancer cells, but not on CSCs, which can make some cancers resistant to this drug. In general, resistance to chemotherapy is caused by the overexpression of one or more $\mathrm{ABC}$ transporters, including $\mathrm{ABCG} 2$ and $\mathrm{ABCB} 1 /$ multidrug resistance protein 1 (MDR1) [165]. Studies of nasopharyngeal carcinoma cells (NCS) have shown that while 5-FU treatment increases the CSCs population and COX-2 expression, PN reduces CSCs and downregulates COX-2. Studies conducted by Liao et al. [166] have shown that PN induces cell death in CSCs of NCS by inhibiting the NF-kB/COX-2 pathway.

\section{Pathenolide Therapeutic Potential and Parthenolide Analogues}

\subsection{Synergistic Action of PN with Other Coumponds}

From the evidence reported so far, PN represents a promising chemotherapy agent. Its effectiveness can be used in synergy with other anticancer agents of various types [22] (Table 1), with the aim of reducing the doses of the compounds used and preventing the onset of chemoresistance.

The combination of PN with Taxol has also been shown to be effective in lung cancer xenografts as described by Zang et al. [167]. Similarly, a PN analogue has been found to suppress in vivo prostate cancer growth and potentiate the effect of docetaxel [27]. The same authors have previously reported the in vivo effects of PN in combination with docetaxel in prostate cancer [168].

As described in the previous paragraph, significant results have also been found by Liu et al. [164], who combined PN stealthy liposomes with vinorelbine stealthy liposomes to treat breast cancer stem cells in both in vitro and in xenograft models. 
In breast cancer, PN has also been shown to enhance sensitivity to antiestrogen such as tamoxifen [169] or fulvestrant [170], an effect which was mainly correlated with inhibition of NF-KB.

Other studies [171] of triple negative breast cancer cells have shown that PN sensitizes breast cancer cells to suberoylanilide hydroxamic acid (SAHA), a histone deacetylase inhibitor. One study showed that, in MDA-MB231 cells, the association of PN to SAHA inhibits the cytoprotective responses induced by the single compounds, while the cytotoxic effects are enhanced [171].

In lung cancer cells, Fang et al. have observed an increased susceptibility to low doses of oxaliplatin [172].

In addition to its anticancer properties, PN seems to exert beneficial effects in combination with chemotherapeutic drugs as reported by Francescato et al. [173] who showed its ability to reduce cisplatin-induced renal damage in mice.

Table 1. Main classes of compounds that have a synergistic action in association with PN.

\begin{tabular}{|c|c|c|c|}
\hline Synergistic Action of PN & & & \\
\hline Coumpounds & Class of Compound & Tested on & Ref. \\
\hline Taxol, Docetaxel, Vinorelbine & Antimicrotubule agents & $\begin{array}{l}\text { Lung cancer, prostate cancer, breast } \\
\text { cancer cell lines }\end{array}$ & {$[164,167,168]$} \\
\hline Tamoxifen, Fulvestrant & Antiestrogen agents & Breast cancer cell lines & {$[169,170]$} \\
\hline SAHA & Histone deacetylase inhibitor & Breast cancer cell lines & [171] \\
\hline Oxaliplatin & Antineoplastic platinum drugs & Lung cancer cell lines & [172] \\
\hline Epirubicin & Anthracycline doxorubicin analog & Breast cancer cell lines & [174] \\
\hline NS398, sulindac & COX-2 inhibitors & Hepatocellular carcinoma cell lines & {$[175,176]$} \\
\hline Dehydroepiandrosterone & Steroid anti-inflammatory agents & Pituitary tumor cell lines & [177] \\
\hline Retinoic acid & Active metabolite of vitamin A & Leukaemia cell lines & [93] \\
\hline Arsenic trioxide & Toxic metalloid & Leukaemia cell lines & [178] \\
\hline TRAIL & Tumor necrosis factor family & $\begin{array}{l}\text { Hepatocellular carcinoma and } \\
\text { breast cancer cell lines }\end{array}$ & {$[50,65,179]$} \\
\hline Radiotherapy & X-ray & $\begin{array}{l}\text { Lung adenocarcinoma, prostate } \\
\text { cancer cell lines }\end{array}$ & {$[50,179-181]$} \\
\hline
\end{tabular}

More recently, evidence has indicated that PN strongly potentiates the effect of epirubicin in breast cancer cells [174].

Preclinical studies have also highlighted the efficacy of PN, or its analogues, in combination with nonconventional antitumor agents including COX-2 inhibitors [175], sulindac [176], steroid anti-inflammatory agents [177], retinoic acid [93], arsenic trioxide [178] and TRAIL [65,102].

Due to inhibition of NF-kB, PN has been shown to increase X-ray sensitivity of tumor cells [50,179]. Moreover, thermoenhancement effects of PN in lung adenocarcinoma cells have suggested a possible combination with hyperthermia as a novel approach in cancer treatment $[180,181]$.

\subsection{Parthenolide Anologues}

It should be noted that the studies conducted with PN have highlighted both its potential and limitations. The limits of PN are due to its poor solubility in water and poor stability. Researchers have tried to overcome these limits to make the compound even more effective. Several studies have been conducted that have aimed to make PN more soluble and stable while preserving its bioactivities $[2,158]$ (Table 2). 
Table 2. Main compounds with structural and functional analogy to PN.

\begin{tabular}{|c|c|c|c|}
\hline PN Anologues & & & \\
\hline Coumpounds & Structure & Tested on & Ref. \\
\hline $\begin{array}{l}\text { Dimethylaminoparthenolide } \\
\text { (DMAPT), also known as LC-1 }\end{array}$ & $\begin{array}{l}\text { PN with a methyl group also in the form } \\
\text { of fumarate salt }\end{array}$ & $\begin{array}{l}\text { Leukemia, prostate cancer, breast } \\
\text { cancer }\end{array}$ & {$[26,27,116]$} \\
\hline $\begin{array}{l}\text { PN semicarbazone or } \\
\text { thiosemicarbazone }\end{array}$ & $\begin{array}{c}\text { PN with } \\
\text { semicarbazone/thiosemi-carbazone } \\
\text { groups }\end{array}$ & $\begin{array}{c}\text { Colorectal carcinoma, glioblastoma, } \\
\text { liver carcinoma, gastric cancer and } \\
\text { lung cancer cell lines }\end{array}$ & [182] \\
\hline PN-fGn or DMAPT-fGn & Carboxyl-functionalized nanographene & Pancreatic cancer cell lines & [183] \\
\hline $\begin{array}{l}\text { PLGA-anti CD44-PN } \\
\text { nanoparticles }\end{array}$ & $\begin{array}{c}\text { Polylactide coglycolide (PLGA) } \\
\text { nanoparticles conjugated with antiCD44 }\end{array}$ & Acute myeloid leukemia & [184] \\
\hline Arglabin & Guaianolide sesquiterpene lactone & $\begin{array}{l}\text { Leukemia, human oral squamous } \\
\text { and lung cancer cell lines }\end{array}$ & [185-188] \\
\hline Micheliolide (MCL) & Guaianolide sesquiterpene lactone & $\begin{array}{l}\text { Hepatocellular carcinoma, leukemia } \\
\text { cells }\end{array}$ & {$[185,189-193]$} \\
\hline АСТ001 & $\begin{array}{c}\text { Fumarate salt of } \\
\text { dimethylaminomicheliolide }\end{array}$ & $\begin{array}{c}\text { Breast cancer cells, glioma stem } \\
\text { cells }\end{array}$ & [194-197] \\
\hline
\end{tabular}

For example, researchers attempted to make PN soluble in water by adding a methyl group and formulating the DMAPT in the form of fumarate salt [26,27].

In a recent study by Jia X et al. [182], the structure of PN was combined with semicarbazone/thiosemicarbazone groups. Semicarbazones and thiosemicarbazones have been extensively studied for their anticancer activities. In fact, both chemical substituents can inhibit kinase activity involved in cell proliferation and the development of tumors. Furthermore, thiosemicarbazones are able to chelate transition metals with effective antitumor activity with the substituted semicarbazone. In Jia X et al's study, 21 new derivatives of PN semicarbazone or thiosemicarbazone were synthesized. Most semicarbazone derivatives showed greater cytotoxicity against human tumor cell lines than PN. Five synthesized compounds, including four semicarbazones and one thiosemicarbazone, were tested in MC38 tumor-bearing mice. In vivo results showed that a specific semicarbazone greatly reduced tumor burden [182].

A valid strategy to increase the solubility of a drug and make it more selective towards cancer cells is nanoencapsulation. Based on these considerations, the researchers sought to improve the effect of PN.

Karmakar et al. [183] used carboxyl-functionalized nanographene (fGn) delivery to overcome the extreme hydrophobicity of PN. The authors found that administration of fGn augments the anticancer and apoptotic effects of PN in human pancreatic cancer Panc- 1 cell lines. This effect was accompanied by an increase in ROS production and mitochondrial dysfunction [183].

Darwish NHE et al. [184] designed polylactide co-glycolide (PLGA) nanoparticles conjugated with antiCD44, a highly expressed transmembrane glycoprotein in leukemia cells and encapsulating PN, in order to improve the selectivity by recognizing tumor cells rather than normal cells. Studies conducted on leukemia cells Kasumi-1, KG-1a, and THP1 have shown that PLGA-antiCD44-PN nanoparticles significantly reduce cell viability compared to PN alone [184].

Given the abundance of PN in nature by several researchers, it is used to semisynthesize other sesquiterpene lactones such as arglabin [185] (Figure 6A). Arglabin is a sesquiterpene lactone belonging to the guaianolide subclass, isolated from Artemisia species $[185,186]$. It has strong anticancer activities on leukemia and human oral squamous and lung cancer cells $[187,188]$. The antitumor action of arglabin is due to its ability to inhibit farnesyl transferase, an enzyme that causes the activation of the proto-oncogene RAS [186]. 




(A) Arglabin



(B) Micheliolide (MCL)



(C) ACT001

Figure 6. Chemical structures of (A) arglabin, (B) micheliolide (MCL) and its analogue (C) ACT001.

In addition, micheliolide (MCL), a sesquiterpene lactone that can be produced from PN [185] (Figure 6B), has shown great potential in antitumor treatment [189]. The antitumor action of MCL is due, as well as for PN, to the inhibitions of the NF- KB and the STAT3 signaling pathways [190-192]. Furthermore, MCL induces death in leukemia cells by irreversibly activating pyruvate kinase [193]. ACT001 (Figure 6C) is the fumarate salt of dimethylaminomicheliolide as an orally available derivative of MCL, synthesized from PN by Accendatech Co., Ltd. (Tianjin, China) [194]. ACT001 has a strong anticancer action in breast cancer cells $[195,196]$. It has been shown that ACT001 is also able to inhibit the proliferation of glioma stem cells (GSCs) [197]. Studies conducted in GSC xenografts have shown that ACT001 acts by inhibiting the adipocyte enhancer 1 binding protein (AEBP1), resulting in inhibition of AKT phosphorylation and cell proliferation [197].

\section{Conclusions}

PN exerts its antitumor action through different mechanisms including transcriptional regulation, epigenetic effects, signal transduction modulation and induction of oxidative stress. Through these modalities, $\mathrm{PN}$ is able to induce apoptosis or alternative forms of cell death including "necrosis-like" and "apoptosis-like" programmed cell death as well as autophagic cell death. The compound appears to display selectivity to tumor cells and a particular efficacy in cancer stem cells, which are the cause of relapses and resistance following chemotherapy. Many lines of evidence indicate that PN potentiates the effect of conventional chemotherapeutics or other antitumor drugs in different tumor models. Studies are still underway to make PN a more effective drug by increasing its stability and solubility. For this purpose, some PN analogues have been developed and are currently under investigation in different tumor models. Overall, $\mathrm{PN}$ and its analogues represent promising agents in cancer therapy, and studies on these compounds have served as a basis to synthesize or isolate new sesquiterpene lactones that are increasingly effective to specifically target cancer cells.

Author Contributions: S.E. and D.C. conceived the central idea of the article and performed a preliminary extensive literature review; S.E. wrote the manuscript with support from D.C., M.L. and A.D.; A.C. and G.P. composed figures; A.N., M.G., A.D.B. and G.C. performed complementary literature reviews and revised the manuscript. All authors have read and agreed to the published version of the manuscript.

Funding: This research received no external funding.

Institutional Review Board Statement: Not applicable.

Informed Consent Statement: Not applicable.

Data Availability Statement: Not applicable.

Acknowledgments: This paper is dedicated to the memory of Giovanni Tesoriere, whose devotion to understanding the biochemical mechanisms of parthenolide action was a source of inspiration. 
Conflicts of Interest: The authors declare no conflict of interest.

\section{Abbreviations}

\begin{tabular}{|c|c|}
\hline $5-\mathrm{FU}$ & 5-fluorouracil \\
\hline ABCB1 & ATP-binding cassette subfamily B member 1 \\
\hline ABCG2 & ATP-binding cassette subfamily G member 2 \\
\hline AEBP1 & Adipocyte enhancer-binding protein 1 \\
\hline AIF & Apoptosis inducing factor \\
\hline AML & Acute myeloid leukemia \\
\hline ATM & Ataxia-telangiectasia mutated \\
\hline B-Raf & v-Raf murine sarcoma viral oncogene homolog B1 \\
\hline $\mathrm{BSO}$ & Buthionine sulfoximine \\
\hline $\mathrm{C} / \mathrm{EBP}-\alpha$ & CCAAT enhancer-binding protein alpha \\
\hline CaM kinases & $\mathrm{Ca} 2+/$ calmodulin-dependent protein kinases \\
\hline CDK & Cyclin-dependent kinase \\
\hline c-FLIP & Cellular FLICE (FADD-like IL-1 $\beta$-converting enzyme)-inhibitory protein \\
\hline CML & Chronic myeloid leukemia \\
\hline c-MYB & Cellular myeloblastosis \\
\hline COX-2 & Cyclooxygenase-2 \\
\hline CSCs & Cancer stem cells \\
\hline DMAPT & Dimethylaminoparthenolide \\
\hline DNMT1 & DNA (cytosine-5)-methyltransferase 1 \\
\hline ERK & Extracellular signal-regulated kinase \\
\hline $\mathrm{fGn}$ & Carboxyl-functionalized nanographene \\
\hline FRA-1 & Fos-related antigen 1 \\
\hline GBM & Glioblastoma \\
\hline GSCs & Glioma stem cells \\
\hline GSH & Glutathione \\
\hline $\mathrm{HCC}$ & Hepatocellular carcinoma \\
\hline HDAC1 & Histone deacetylase 1 \\
\hline HMEC & Human mammary epithelial cells \\
\hline HOXA-4 & Homeobox A4 \\
\hline ICAM & Intercellular adhesion molecule \\
\hline $\mathrm{IFN}-\gamma$ & Interferon gamma \\
\hline $\mathrm{IkB}$ & Inhibitor of NF- $\mathrm{KB}$ \\
\hline IKC & IkB kinase complex \\
\hline $\mathrm{IKK} \alpha$ & IkappaB kinase alpha \\
\hline $\mathrm{IKK} \beta$ & IkappaB kinase beta \\
\hline IL-1 & Interleukin-1 \\
\hline IL-2 & Interleukin-2 \\
\hline IL-4 & Interleukin-4 \\
\hline IL-6 & Interleukin-6 \\
\hline iNOS & Inducible nitric oxide synthase \\
\hline JAK & Janus kinase \\
\hline JNK & c-Jun N-terminal kinase \\
\hline LEF1 & Lymphoid enhancer-binding factor 1 \\
\hline LSCs & Leukemia stem cells \\
\hline MAPKs & Mitogen-activated protein kinases \\
\hline MCL-1 & Myeloid cell leukemia 1 \\
\hline MDM2 & Murine double minute 2 \\
\hline MDR1 & Multidrug resistance protein 1 \\
\hline MITF & Melanocyte-inducing transcription factor \\
\hline $\mathrm{MM}$ & Multiple myeloma \\
\hline MM-CSCs & Multiple myeloma cancer stem cells \\
\hline Mn-SOD & Manganese superoxide dismutase \\
\hline
\end{tabular}






\section{References}

1. Sur, R.; Martin, K.; Liebel, F.; Lyte, P.; Shapiro, S.; Southall, M. Anti-Inflammatory Activity of Parthenolide-Depleted Feverfew (Tanacetum Parthenium). Inflammopharmacology 2009, 17, 42-49. [CrossRef]

2. Freund, R.R.A.; Gobrecht, P.; Fischer, D.; Arndt, H.-D. Advances in Chemistry and Bioactivity of Parthenolide. Nat. Prod. Rep. 2020, 37, 541-565. [CrossRef]

3. Juliana, C.; Fernandes-Alnemri, T.; Wu, J.; Datta, P.; Solorzano, L.; Yu, J.-W.; Meng, R.; Quong, A.A.; Latz, E.; Scott, C.P.; et al. AntiInflammatory Compounds Parthenolide and Bay 11-7082 Are Direct Inhibitors of the Inflammasome. J. Biol. Chem. 2010, 285, 9792-9802. [CrossRef]

4. Ghantous, A.; Sinjab, A.; Herceg, Z.; Darwiche, N. Parthenolide: From Plant Shoots to Cancer Roots. Drug Discov. Today 2013, 18, 894-905. [CrossRef]

5. Pajak, B.; Gajkowska, B.; Orzechowski, A. Molecular Basis of Parthenolide-Dependent Proapoptotic Activity in Cancer Cells. Folia Histochem. Cytobiol. 2008, 46, 129-135. [CrossRef]

6. Li-Weber, M.; Palfi, K.; Giaisi, M.; Krammer, P.H. Dual Role of the Anti-Inflammatory Sesquiterpene Lactone: Regulation of Life and Death by Parthenolide. Cell Death Differ. 2005, 12, 408-409. [CrossRef]

7. Zhang, S.; Ong, C.-N.; Shen, H.-M. Critical Roles of Intracellular Thiols and Calcium in Parthenolide-Induced Apoptosis in Human Colorectal Cancer Cells. Cancer Lett. 2004, 208, 143-153. [CrossRef]

8. Skalska, J.; Brookes, P.S.; Nadtochiy, S.M.; Hilchey, S.P.; Jordan, C.T.; Guzman, M.L.; Maggirwar, S.B.; Briehl, M.M.; Bernstein, S.H. Modulation of Cell Surface Protein Free Thiols: A Potential Novel Mechanism of Action of the Sesquiterpene Lactone Parthenolide. PLoS ONE 2009, 4, e8115. [CrossRef]

9. Dawood, M.; Ooko, E.; Efferth, T. Collateral Sensitivity of Parthenolide via NF-kB and HIF- $\alpha$ Inhibition and Epigenetic Changes in Drug-Resistant Cancer Cell Lines. Front. Pharmacol. 2019, 10, 542. [CrossRef]

10. Nam, Y.J.; Lee, D.H.; Lee, M.S.; Lee, C.S. Sesquiterpene Lactone Parthenolide Attenuates Production of Inflammatory Mediators by Suppressing the Toll-like Receptor-4-Mediated Activation of the Akt, MTOR, and NF-kB Pathways. Naunyn-Schmiedeberg's Arch. Pharm. 2015, 388, 921-930. [CrossRef]

11. López-Franco, O.; Hernández-Vargas, P.; Ortiz-Muñoz, G.; Sanjuán, G.; Suzuki, Y.; Ortega, L.; Blanco, J.; Egido, J.; GómezGuerrero, C. Parthenolide Modulates the NF-kB-Mediated Inflammatory Responses in Experimental Atherosclerosis. Arterioscler. Thromb. Vasc. Biol. 2006, 26, 1864-1870. [CrossRef] [PubMed]

12. Rahman, M.M.; Mohamed, M.R.; Kim, M.; Smallwood, S.; McFadden, G. Co-Regulation of NF-кB and Inflammasome-Mediated Inflammatory Responses by Myxoma Virus Pyrin Domain-Containing Protein M013. PLoS Pathog. 2009, 5, e1000635. [CrossRef] [PubMed]

13. Liu, T.; Zhang, L.; Joo, D.; Sun, S.-C. NF-kB Signaling in Inflammation. Signal Transduct. Target. 2017, 2, 17023. [CrossRef] [PubMed] 
14. Zinatizadeh, M.R.; Schock, B.; Chalbatani, G.M.; Zarandi, P.K.; Jalali, S.A.; Miri, S.R. The Nuclear Factor Kappa B (NF-kB) Signaling in Cancer Development and Immune Diseases. Genes Dis. 2021, 8, 287-297. [CrossRef]

15. Aoyagi, T.; Terracina, K.P.; Raza, A.; Matsubara, H.; Takabe, K. Cancer Cachexia, Mechanism and Treatment. World J. Gastrointest. Oncol. 2015, 7, 17-29. [CrossRef]

16. Santos, J.M.O.; Moreira-Pais, A.; Neto, T.; Peixoto da Silva, S.; Oliveira, P.A.; Ferreira, R.; Mendes, J.; Bastos, M.M.S.M.; Lopes, C.; Casaca, F.; et al. Dimethylaminoparthenolide Reduces the Incidence of Dysplasia and Ameliorates a Wasting Syndrome in HPV16-Transgenic Mice. Drug Dev. Res. 2019, 80, 824-830. [CrossRef]

17. Ren, Y.; Li, Y.; Lv, J.; Guo, X.; Zhang, J.; Zhou, D.; Zhang, Z.; Xue, Z.; Yang, G.; Xi, Q.; et al. Parthenolide Regulates Oxidative Stress-Induced Mitophagy and Suppresses Apoptosis through P53 Signaling Pathway in C2C12 Myoblasts. J. Cell. Biochem. 2019, 120, 15695-15708. [CrossRef]

18. Mathema, V.B.; Koh, Y.-S.; Thakuri, B.C.; Sillanpää, M. Parthenolide, a Sesquiterpene Lactone, Expresses Multiple Anti-Cancer and Anti-Inflammatory Activities. Inflammation 2012, 35, 560-565. [CrossRef]

19. Wang, M.; Li, Q. Parthenolide Could Become a Promising and Stable Drug with Anti-Inflammatory Effects. Nat. Prod. Res. 2015, 29, 1092-1101. [CrossRef]

20. Chen, C.-F.C.; Leung, A.Y.L.Y. Gene Response of Human Monocytic Cells for the Detection of Antimigraine Activity of Feverfew ExtractsThis Article Is One of a Selection of Papers Published in This Special Issue (Part 2 of 2) on the Safety and Efficacy of Natural Health Products. Can. J. Physiol. Pharmacol. 2007. [CrossRef]

21. Brown, R.P.; Gerbarg, P.L. Herbs and Nutrients in the Treatment of Depression, Anxiety, Insomnia, Migraine, and Obesity. J. Psychiatr. Pract. 2001, 7, 75-91. [CrossRef] [PubMed]

22. Sztiller-Sikorska, M.; Czyz, M. Parthenolide as Cooperating Agent for Anti-Cancer Treatment of Various Malignancies Pharmaceuticals 2020, 13, 194. [CrossRef] [PubMed]

23. Liu, Y.C.; Kim, S.L.; Park, Y.R.; Lee, S.-T.; Kim, S.W. Parthenolide Promotes Apoptotic Cell Death and Inhibits the Migration and Invasion of SW620 Cells. Intestig. Res. 2017, 15, 174-181. [CrossRef] [PubMed]

24. Yang, C.; Yang, Q.O.; Kong, Q.-J.; Yuan, W.; Yang, Y.-P.O. Parthenolide Induces Reactive Oxygen Species-Mediated Autophagic Cell Death in Human Osteosarcoma Cells. Cell. Physiol. Biochem. 2016, 40, 146-154. [CrossRef]

25. Hexum, J.K.; Becker, C.M.; Kempema, A.M.; Ohlfest, J.R.; Largaespada, D.A.; Harki, D.A. Parthenolide Prodrug LC-1 Slows Growth of Intracranial Glioma. Bioorg. Med. Chem. Lett. 2015, 25, 2493-2495. [CrossRef]

26. Guzman, M.L.; Rossi, R.M.; Neelakantan, S.; Li, X.; Corbett, C.A.; Hassane, D.C.; Becker, M.W.; Bennett, J.M.; Sullivan, E.; Lachowicz, J.L.; et al. An Orally Bioavailable Parthenolide Analog Selectively Eradicates Acute Myelogenous Leukemia Stem and Progenitor Cells. Blood 2007, 110, 4427-4435. [CrossRef]

27. Shanmugam, R.; Kusumanchi, P.; Cheng, L.; Crooks, P.; Neelakantan, S.; Matthews, W.; Nakshatri, H.; Sweeney, C.J. A WaterSoluble Parthenolide Analogue Suppresses in Vivo Prostate Cancer Growth by Targeting NFkB and Generating Reactive Oxygen Species. Prostate 2010, 70, 1074-1086. [CrossRef]

28. Avci, N.G.; Ebrahimzadeh-Pustchi, S.; Akay, Y.M.; Esquenazi, Y.; Tandon, N.; Zhu, J.-J.; Akay, M. NF-kB Inhibitor with Temozolomide Results in Significant Apoptosis in Glioblastoma via the NF-кB(P65) and Actin Cytoskeleton Regulatory Pathways. Sci. Rep. 2020, 10, 13352. [CrossRef]

29. Arora, R.; Yates, C.; Gary, B.D.; McClellan, S.; Tan, M.; Xi, Y.; Reed, E.; Piazza, G.A.; Owen, L.B.; Dean-Colomb, W. Panepoxydone Targets NF- $\mathrm{B}$ and FOXM1 to Inhibit Proliferation, Induce Apoptosis and Reverse Epithelial to Mesenchymal Transition in Breast Cancer. PLoS ONE 2014, 9, e98370. [CrossRef]

30. Singh, V.; Gupta, D.; Arora, R. NF- $\kappa B$ as a Key Player in Regulation of Cellular Radiation Responses and Identification of Radiation Countermeasures. Discoveries 2015, 3, e35. [CrossRef]

31. Hellweg, C.E. The Nuclear Factor KB Pathway: A Link to the Immune System in the Radiation Response. Cancer Lett. 2015, 368, 275-289. [CrossRef] [PubMed]

32. Benedetti, G.; Fredriksson, L.; Herpers, B.; Meerman, J.; van de Water, B.; de Graauw, M. TNF- $\alpha$-Mediated NF-kB Survival Signaling Impairment by Cisplatin Enhances JNK Activation Allowing Synergistic Apoptosis of Renal Proximal Tubular Cells. Biochem. Pharmacol. 2013, 85, 274-286. [CrossRef] [PubMed]

33. Rex, J.; Lutz, A.; Faletti, L.E.; Albrecht, U.; Thomas, M.; Bode, J.G.; Borner, C.; Sawodny, O.; Merfort, I. IL-1 $\beta$ and TNF $\alpha$ Differentially Influence NF- $\mathrm{BB}$ Activity and FasL-Induced Apoptosis in Primary Murine Hepatocytes during LPS-Induced Inflammation. Front. Physiol. 2019, 10, 177. [CrossRef] [PubMed]

34. Lingappan, K. NF-кB in Oxidative Stress. Curr. Opin. Toxicol. 2018, 7, 81-86. [CrossRef] [PubMed]

35. Morgan, M.J.; Liu, Z. Crosstalk of Reactive Oxygen Species and NF-kB Signaling. Cell Res. 2011, 21, 103-115. [CrossRef]

36. Chaithongyot, S.; Jantaree, P.; Sokolova, O.; Naumann, M. NF-кB in Gastric Cancer Development and Therapy. Biomedicines 2021, 9, 870. [CrossRef]

37. Zhang, Q.; Lenardo, M.J.; Baltimore, D. 30 Years of NF-kB: A Blossoming of Relevance to Human Pathobiology. Cell 2017, 168, 37-57. [CrossRef]

38. Singh, S.; Singh, T.G. Role of Nuclear Factor Kappa B (NF-кB) Signalling in Neurodegenerative Diseases: An Mechanistic Approach. Curr. Neuropharmacol. 2020, 18, 918-935. [CrossRef]

39. Hehner, S.P.; Hofmann, T.G.; Dröge, W.; Schmitz, M.L. The Antiinflammatory Sesquiterpene Lactone Parthenolide Inhibits NF- $k B$ by Targeting the IкB Kinase Complex. J. Immunol. 1999, 163, 5617-5623. 
40. Kwok, B.H.B.; Koh, B.; Ndubuisi, M.I.; Elofsson, M.; Crews, C.M. The Anti-Inflammatory Natural Product Parthenolide from the Medicinal Herb Feverfew Directly Binds to and Inhibits IкB Kinase. Chem. Biol. 2001, 8, 759-766. [CrossRef]

41. Idris, A.I.; Libouban, H.; Nyangoga, H.; Landao-Bassonga, E.; Chappard, D.; Ralston, S.H. Pharmacologic Inhibitors of IkB Kinase Suppress Growth and Migration of Mammary Carcinosarcoma Cells in Vitro and Prevent Osteolytic Bone Metastasis in Vivo. Mol. Cancer 2009, 8, 2339-2347. [CrossRef] [PubMed]

42. Yip, K.H.M.; Zheng, M.H.; Feng, H.T.; Steer, J.H.; Joyce, D.A.; Xu, J. Sesquiterpene Lactone Parthenolide Blocks LipopolysaccharideInduced Osteolysis Through the Suppression of NF-кB Activity. J. Bone Miner. Res. 2004, 19, 1905-1916. [CrossRef] [PubMed]

43. Zhang, S.; Lin, Z.-N.; Yang, C.-F.; Shi, X.; Ong, C.-N.; Shen, H.-M. Suppressed NF-kB and Sustained JNK Activation Contribute to the Sensitization Effect of Parthenolide to TNF- $\alpha$-Induced Apoptosis in Human Cancer Cells. Carcinogenesis 2004, 25, 2191-2199. [CrossRef] [PubMed]

44. Buhrmann, C.; Shayan, P.; Banik, K.; Kunnumakkara, A.B.; Kubatka, P.; Koklesova, L.; Shakibaei, M. Targeting NF-kB Signaling by Calebin A, a Compound of Turmeric, in Multicellular Tumor Microenvironment: Potential Role of Apoptosis Induction in CRC Cells. Biomedicines 2020, 8, 236. [CrossRef]

45. Park, S.H.; Riley, P.; Frisch, S.M. Regulation of Anoikis by Deleted in Breast Cancer-1 (DBC1) through NF-kB. Apoptosis 2013, 18, 949-962. [CrossRef]

46. Verzella, D.; Pescatore, A.; Capece, D.; Vecchiotti, D.; Ursini, M.V.; Franzoso, G.; Alesse, E.; Zazzeroni, F. Life, Death, and Autophagy in Cancer: NF-kB Turns up Everywhere. Cell Death Dis. 2020, 11, 210. [CrossRef]

47. Xia, Y.; Shen, S.; Verma, I.M. NF-kB, an Active Player in Human Cancers. Cancer Immunol. Res. 2014, 2, 823-830. [CrossRef]

48. Kim, S.-L.; Kim, S.H.; Park, Y.R.; Liu, Y.-C.; Kim, E.-M.; Jeong, H.-J.; Kim, Y.N.; Seo, S.Y.; Kim, I.H.; Lee, S.O.; et al. Combined Parthenolide and Balsalazide Have Enhanced Antitumor Efficacy Through Blockade of NF-kB Activation. Mol. Cancer Res. 2017, 15, 141-151. [CrossRef]

49. Kim, S.-L.; Kim, S.H.; Trang, K.T.T.; Kim, I.H.; Lee, S.-O.; Lee, S.T.; Kim, D.G.; Kang, S.-B.; Kim, S.-W. Synergistic Antitumor Effect of 5-Fluorouracil in Combination with Parthenolide in Human Colorectal Cancer. Cancer Lett. 2013, 335, 479-486. [CrossRef]

50. Mendonca, M.S.; Chin-Sinex, H.; Gomez-Millan, J.; Datzman, N.; Hardacre, M.; Comerford, K.; Nakshatri, H.; Nye, M.; Benjamin, L.; Mehta, S.; et al. Parthenolide Sensitizes Cells to X-Ray-Induced Cell Killing through Inhibition of NF-kB and Split-Dose Repair. Radiat. Res. 2007, 168, 689-697. [CrossRef]

51. Sun, Y.; Clair, D.K.S.; Fang, F.; Warren, G.W.; Rangnekar, V.M.; Crooks, P.A.; Clair, W.H.S. The Radiosensitization Effect of Parthenolide in Prostate Cancer Cells Is Mediated by Nuclear Factor-KB Inhibition and Enhanced by the Presence of PTEN. Mol. Cancer 2007, 6, 2477-2486. [CrossRef] [PubMed]

52. Shao, L.; Wu, L.; Zhou, D. Sensitization of Tumor Cells to Cancer Therapy by Molecularly Targeted Inhibition of the Inhibitor of Nuclear Factor KB Kinase. Transl. Cancer Res. 2012, 1, 100-108. [CrossRef] [PubMed]

53. Morel, K.L.; Ormsby, R.J.; Bezak, E.; Sweeney, C.J.; Sykes, P.J. Parthenolide Selectively Sensitizes Prostate Tumor Tissue to Radiotherapy While Protecting Healthy Tissues In Vivo. Radiat. Res. 2017, 187, 501-512. [CrossRef] [PubMed]

54. Yin, Q.; Wang, L.; Yu, H.; Chen, D.; Zhu, W.; Sun, C. Pharmacological Effects of Polyphenol Phytochemicals on the JAK-STAT Signaling Pathway. Front. Pharmacol. 2021, 12, 2350. [CrossRef] [PubMed]

55. Verhoeven, Y.; Tilborghs, S.; Jacobs, J.; De Waele, J.; Quatannens, D.; Deben, C.; Prenen, H.; Pauwels, P.; Trinh, X.B.; Wouters, A.; et al. The Potential and Controversy of Targeting STAT Family Members in Cancer. Semin. Cancer Biol. 2020, 60, 41-56. [CrossRef]

56. Awasthi, N.; Liongue, C.; Ward, A.C. STAT Proteins: A Kaleidoscope of Canonical and Non-Canonical Functions in Immunity and Cancer. J. Hematol. Oncol. 2021, 14, 198. [CrossRef]

57. Hu, X.; Li, J.; Fu, M.; Zhao, X.; Wang, W. The JAK/STAT Signaling Pathway: From Bench to Clinic. Signal Transduct. Target. 2021, 6, 402. [CrossRef]

58. Arumuggam, N.; Bhowmick, N.A.; Rupasinghe, H.P.V. A Review: Phytochemicals Targeting JAK/STAT Signaling and IDO Expression in Cancer. Phytother. Res. 2015, 29, 805-817. [CrossRef]

59. Heppler, L.N.; Frank, D.A. Targeting Oncogenic Transcription Factors: Therapeutic Implications of Endogenous STAT Inhibitors. Trends Cancer 2017, 3, 816-827. [CrossRef]

60. Tolomeo, M.; Cascio, A. The Multifaced Role of STAT3 in Cancer and Its Implication for Anticancer Therapy. Int. J. Mol. Sci. 2021, 22, 603. [CrossRef]

61. Tošić, I.; Frank, D.A. STAT3 as a Mediator of Oncogenic Cellular Metabolism: Pathogenic and Therapeutic Implications. Neoplasia 2021, 23, 1167-1178. [CrossRef] [PubMed]

62. Liu, Y.; Liao, S.; Bennett, S.; Tang, H.; Song, D.; Wood, D.; Zhan, X.; Xu, J. STAT3 and Its Targeting Inhibitors in Osteosarcoma. Cell Prolif. 2021, 54, e12974. [CrossRef] [PubMed]

63. Zhang, C.; Li, B.; Gaikwad, A.S.; Haridas, V.; Xu, Z.; Gutterman, J.U.; Duvic, M. Avicin D Selectively Induces Apoptosis and Downregulates P-STAT-3, Bcl-2, and Survivin in Cutaneous T-Cell Lymphoma Cells. J. Investig. Dermatol. 2008, 128, $2728-2735$. [CrossRef] [PubMed]

64. Loh, C.-Y.; Arya, A.; Naema, A.F.; Wong, W.F.; Sethi, G.; Looi, C.Y. Signal Transducer and Activator of Transcription (STATs) Proteins in Cancer and Inflammation: Functions and Therapeutic Implication. Front. Oncol. 2019, 9, 48. [CrossRef] [PubMed]

65. Carlisi, D.; D'Anneo, A.; Angileri, L.; Lauricella, M.; Emanuele, S.; Santulli, A.; Vento, R.; Tesoriere, G. Parthenolide Sensitizes Hepatocellular Carcinoma Cells to Trail by Inducing the Expression of Death Receptors through Inhibition of STAT3 Activation. J. Cell. Physiol. 2011, 226, 1632-1641. [CrossRef] [PubMed] 
66. Sobota, R.; Szwed, M.; Kasza, A.; Bugno, M.; Kordula, T. Parthenolide Inhibits Activation of Signal Transducers and Activators of Transcription (STATs) Induced by Cytokines of the IL-6 Family. Biochem. Biophys. Res. Commun. 2000, 267, 329-333. [CrossRef]

67. Liu, M.; Xiao, C.; Sun, M.; Tan, M.; Hu, L.; Yu, Q. Parthenolide Inhibits STAT3 Signaling by Covalently Targeting Janus Kinases. Molecules 2018, 23, 1478. [CrossRef]

68. Cui, Z.-Y.; Wang, G.; Zhang, J.; Song, J.; Jiang, Y.-C.; Dou, J.-Y.; Lian, L.-H.; Nan, J.-X.; Wu, Y.-L. Parthenolide, Bioactive Compound of Chrysanthemum parthenium L., Ameliorates Fibrogenesis and Inflammation in Hepatic Fibrosis via Regulating the Crosstalk of TLR4 and STAT3 Signaling Pathway. Phytother. Res. 2021, 35, 5680-5693. [CrossRef]

69. Li, H.; Lu, H.; Lv, M.; Wang, Q.; Sun, Y. Parthenolide Facilitates Apoptosis and Reverses Drug-Resistance of Human Gastric Carcinoma Cells by Inhibiting the STAT3 Signaling Pathway. Oncol. Lett. 2018, 15, 3572-3579. [CrossRef]

70. Mohammadi, S.; Zahedpanah, M.; Nikbakht, M.; Shaiegan, M.; Hamidollah, G.; Nikugoftar, M.; Rahmani, B.; Hamedi Asl, D. Parthenolide Reduces Gene Transcription of Prosurvival Mediators in U937 Cells. Exp. Oncol. 2017, 39, 30-35. [CrossRef]

71. Wu, Z.; Nicoll, M.; Ingham, R.J. AP-1 Family Transcription Factors: A Diverse Family of Proteins That Regulate Varied Cellular Activities in Classical Hodgkin Lymphoma and ALK+ ALCL. Exp. Hematol. Oncol. 2021, 10, 4. [CrossRef] [PubMed]

72. Atsaves, V.; Leventaki, V.; Rassidakis, G.Z.; Claret, F.X. AP-1 Transcription Factors as Regulators of Immune Responses in Cancer. Cancers 2019, 11, 1037. [CrossRef] [PubMed]

73. Hartman, M.L.; Talar, B.; Sztiller-Sikorska, M.; Nejc, D.; Czyz, M. Parthenolide Induces MITF-M Downregulation and Senescence in Patient-Derived MITF-M High Melanoma Cell Populations. Oncotarget 2016, 7, 9026-9040. [CrossRef]

74. Zhang, J.; Mou, Y.; Gong, H.; Chen, H.; Xiao, H. Microphthalmia-Associated Transcription Factor in Senescence and Age-Related Diseases. Gerontology 2021, 67, 708-717. [CrossRef] [PubMed]

75. Bourseguin, J.; Bonet, C.; Renaud, E.; Pandiani, C.; Boncompagni, M.; Giuliano, S.; Pawlikowska, P.; Karmous-Benailly, H.; Ballotti, R.; Rosselli, F.; et al. FANCD2 Functions as a Critical Factor Downstream of MiTF to Maintain the Proliferation and Survival of Melanoma Cells. Sci. Rep. 2016, 6, 36539. [CrossRef] [PubMed]

76. Trejo-Solis, C.; Escamilla-Ramirez, A.; Jimenez-Farfan, D.; Castillo-Rodriguez, R.A.; Flores-Najera, A.; Cruz-Salgado, A. Crosstalk of the Wnt/ $\beta$-Catenin Signaling Pathway in the Induction of Apoptosis on Cancer Cells. Pharmaceuticals 2021, 14, 871. [CrossRef]

77. Yu, F.; Yu, C.; Li, F.; Zuo, Y.; Wang, Y.; Yao, L.; Wu, C.; Wang, C.; Ye, L. Wnt/ $\beta$-Catenin Signaling in Cancers and Targeted Therapies. Signal Transduct. Target. 2021, 6, 307. [CrossRef]

78. Zhu, X.; Yuan, C.; Tian, C.; Li, C.; Nie, F.; Song, X.; Zeng, R.; Wu, D.; Hao, X.; Li, L. The Plant Sesquiterpene Lactone Parthenolide Inhibits Wnt/ $\beta$-Catenin Signaling by Blocking Synthesis of the Transcriptional Regulators TCF4/LEF1. J. Biol. Chem. 2018, 293, 5335-5344. [CrossRef]

79. Lees, A.; Sessler, T.; McDade, S. Dying to Survive-The P53 Paradox. Cancers 2021, 13, 3257. [CrossRef]

80. Lukin, D.J.; Carvajal, L.A.; Liu, W.; Resnick-Silverman, L.; Manfredi, J.J. P53 Promotes Cell Survival Due to the Reversibility of Its Cell-Cycle Checkpoints. Mol. Cancer Res. 2015, 13, 16-28. [CrossRef]

81. Guadagno, J.; Swan, P.; Shaikh, R.; Cregan, S.P. Microglia-Derived IL-1 $\beta$ Triggers P53-Mediated Cell Cycle Arrest and Apoptosis in Neural Precursor Cells. Cell Death Dis. 2015, 6, e1779. [CrossRef] [PubMed]

82. Hou, H.; Sun, D.; Zhang, X. The Role of MDM2 Amplification and Overexpression in Therapeutic Resistance of Malignant Tumors. Cancer Cell Int. 2019, 19, 216. [CrossRef] [PubMed]

83. Gopal, Y.N.V.; Chanchorn, E.; Dyke, M.W.V. Parthenolide Promotes the Ubiquitination of MDM2 and Activates P53 Cellular Functions. Mol. Cancer 2009, 8, 552-562. [CrossRef] [PubMed]

84. Al-Fatlawi, A.A.; Al-Fatlawi, A.A.; Irshad, M.; Rahisuddin; Ahmad, A. Effect of parthenolide on growth and apoptosis regulatory genes of human cancer cell lines. Pharm. Biol. 2015, 53, 104-109. [CrossRef] [PubMed]

85. Talib, W.H.; Al Kury, L.T. Parthenolide Inhibits Tumor-Promoting Effects of Nicotine in Lung Cancer by Inducing P53-Dependent Apoptosis and Inhibiting VEGF Expression. Biomed. Pharmacother. 2018, 107, 1488-1495. [CrossRef]

86. Steele, A.J.; Jones, D.T.; Ganeshaguru, K.; Duke, V.M.; Yogashangary, B.C.; North, J.M.; Lowdell, M.W.; Kottaridis, P.D.; Mehta, A.B.; Prentice, A.G.; et al. The Sesquiterpene Lactone Parthenolide Induces Selective Apoptosis of B-Chronic Lymphocytic Leukemia Cells in Vitro. Leukemia 2006, 20, 1073-1079. [CrossRef]

87. Ghantous, A.; Saikali, M.; Rau, T.; Gali-Muhtasib, H.; Schneider-Stock, R.; Darwiche, N. Inhibition of Tumor Promotion by Parthenolide: Epigenetic Modulation of P21. Cancer Prev. Res. 2012, 5, 1298-1309. [CrossRef]

88. Dey, S.; Sarkar, M.; Giri, B. Anti-Inflammatory and Anti-Tumor Activities of Parthenolide: An Update. J. Chem. Biol. 2016, 1, 107. [CrossRef]

89. Gopal, Y.N.V.; Arora, T.S.; Van Dyke, M.W. Parthenolide Specifically Depletes Histone Deacetylase 1 Protein and Induces Cell Death through Ataxia Telangiectasia Mutated. Chem. Biol. 2007, 14, 813-823. [CrossRef]

90. Liu, Z.; Liu, S.; Xie, Z.; Pavlovicz, R.E.; Wu, J.; Chen, P.; Aimiuwu, J.; Pang, J.; Bhasin, D.; Neviani, P.; et al. Modulation of DNA Methylation by a Sesquiterpene Lactone Parthenolide. J. Pharm. Exp. 2009, 329, 505-514. [CrossRef]

91. Irshad, R.; Husain, M. Natural Products in the Reprogramming of Cancer Epigenetics. Toxicol. Appl. Pharmacol. 2021, 417, 115467. [CrossRef] [PubMed]

92. Won, Y.-K.; Ong, C.-N.; Shen, H.-M. Parthenolide Sensitizes Ultraviolet (UV)-B-Induced Apoptosis via Protein Kinase CDependent Pathways. Carcinogenesis 2005, 26, 2149-2156. [CrossRef] [PubMed]

93. Kim, S.H.; Danilenko, M.; Kim, T.S. Differential Enhancement of Leukaemia Cell Differentiation without Elevation of Intracellular Calcium by Plant-Derived Sesquiterpene Lactone Compounds. Br. J. Pharm. 2008, 155, 814-825. [CrossRef] [PubMed] 
94. Kawasaki, B.T.; Hurt, E.M.; Kalathur, M.; Duhagon, M.A.; Milner, J.A.; Kim, Y.S.; Farrar, W.L. Effects of the Sesquiterpene Lactone Parthenolide on Prostate Tumor-Initiating Cells: An Integrated Molecular Profiling Approach. Prostate 2009, 69, 827-837. [CrossRef]

95. Lin, M.; Bi, H.; Yan, Y.; Huang, W.; Zhang, G.; Zhang, G.; Tang, S.; Liu, Y.; Zhang, L.; Ma, J.; et al. Parthenolide Suppresses Non-Small Cell Lung Cancer GLC-82 Cells Growth via B-Raf/MAPK/Erk Pathway. Oncotarget 2017, 8, 23436-23447. [CrossRef]

96. Li, X.; Huang, R.; Li, M.; Zhu, Z.; Chen, Z.; Cui, L.; Luo, H.; Luo, L. Parthenolide Inhibits the Growth of Non-Small Cell Lung Cancer by Targeting Epidermal Growth Factor Receptor. Cancer Cell Int. 2020, 20, 561. [CrossRef]

97. Berdan, C.A.; Ho, R.; Lehtola, H.S.; To, M.; Hu, X.; Huffman, T.R.; Petri, Y.; Altobelli, C.R.; Demeulenaere, S.G.; Olzmann, J.A.; et al Parthenolide Covalently Targets and Inhibits Focal Adhesion Kinase in Breast Cancer Cells. Cell Chem. Biol. 2019, 26, $1027-1035$. [CrossRef]

98. Li, X.; Kong, L.; Yang, Q.; Duan, A.; Ju, X.; Cai, B.; Chen, L.; An, T.; Li, Y. Parthenolide Inhibits Ubiquitin-Specific Peptidase 7 (USP7), Wnt Signaling, and Colorectal Cancer Cell Growth. J. Biol. Chem. 2020, 295, 3576-3589. [CrossRef]

99. Yue, J.; López, J.M. Understanding MAPK Signaling Pathways in Apoptosis. Int. J. Mol. Sci. 2020, 21, 2346. [CrossRef]

100. Ki, Y.-W.; Park, J.H.; Lee, J.E.; Shin, I.C.; Koh, H.C. JNK and P38 MAPK Regulate Oxidative Stress and the Inflammatory Response in Chlorpyrifos-Induced Apoptosis. Toxicol. Lett. 2013, 218, 235-245. [CrossRef]

101. Gao, H.-E.; Sun, Y.; Ding, Y.-H.; Long, J.; Liu, X.-L.; Yang, M.; Ji, Q.; Li, Y.-H.; Chen, Y.; Zhang, Q.; et al. Antineoplastic Effects of CPPTL via the ROS/JNK Pathway in Acute Myeloid Leukemia. Oncotarget 2017, 8, 38990-39000. [CrossRef]

102. Nakshatri, H.; Rice, S.E.; Bhat-Nakshatri, P. Antitumor Agent Parthenolide Reverses Resistance of Breast Cancer Cells to Tumor Necrosis Factor-Related Apoptosis-Inducing Ligand through Sustained Activation of c-Jun N-Terminal Kinase. Oncogene 2004, 23, 7330-7344. [CrossRef] [PubMed]

103. Sui, X.; Kong, N.; Ye, L.; Han, W.; Zhou, J.; Zhang, Q.; He, C.; Pan, H. P38 and JNK MAPK Pathways Control the Balance of Apoptosis and Autophagy in Response to Chemotherapeutic Agents. Cancer Lett. 2014, 344, 174-179. [CrossRef] [PubMed]

104. Achkar, I.W.; Abdulrahman, N.; Al-Sulaiti, H.; Joseph, J.M.; Uddin, S.; Mraiche, F. Cisplatin Based Therapy: The Role of the Mitogen Activated Protein Kinase Signaling Pathway. J. Transl. Med. 2018, 16, 96. [CrossRef] [PubMed]

105. Lee, S.; Rauch, J.; Kolch, W. Targeting MAPK Signaling in Cancer: Mechanisms of Drug Resistance and Sensitivity. Int. J. Mol. Sci. 2020, 21, 1102. [CrossRef] [PubMed]

106. Wagner, E.F.; Nebreda, Á.R. Signal Integration by JNK and P38 MAPK Pathways in Cancer Development. Nat. Rev. Cancer 2009, 9, 537-549. [CrossRef] [PubMed]

107. Qin, Y.; Auh, S.; Blokh, L.; Long, C.; Gagnon, I.; Hamann, K.J. TNF- $\alpha$ Induces Transient Resistance to Fas-Induced Apoptosis in Eosinophilic Acute Myeloid Leukemia Cells. Mol. Immunol. 2007, 4, 10.

108. Chen, Y.-T.; Lin, C.-W.; Su, C.-W.; Yang, W.-E.; Chuang, C.-Y.; Su, S.-C.; Hsieh, M.-J.; Yang, S.-F. Magnolol Triggers CaspaseMediated Apoptotic Cell Death in Human Oral Cancer Cells through JNK1/2 and P38 Pathways. Biomedicines 2021, 9, 1295. [CrossRef]

109. D'Arcy, M.S. Cell Death: A Review of the Major Forms of Apoptosis, Necrosis and Autophagy. Cell Biol. Int. 2019, 43, 582-592. [CrossRef]

110. Chen, Q.; Kang, J.; Fu, C. The Independence of and Associations among Apoptosis, Autophagy, and Necrosis. Signal Transduct. Target. 2018, 3, 18. [CrossRef]

111. Zhao, X.; Liu, X.; Su, L. Parthenolide Induces Apoptosis via TNFRSF10B and PMAIP1 Pathways in Human Lung Cancer Cells. J. Exp. Clin. Cancer Res. 2014, 33, 3. [CrossRef] [PubMed]

112. Suvannasankha, A.; Crean, C.D.; Shanmugam, R.; Farag, S.S.; Abonour, R.; Boswell, H.S.; Nakshatri, H. Antimyeloma Effects of a Sesquiterpene Lactone Parthenolide. Clin. Cancer Res. 2008, 14, 1814-1822. [CrossRef] [PubMed]

113. Karam, L.; Abou Staiteieh, S.; Chaaban, R.; Hayar, B.; Ismail, B.; Neipel, F.; Darwiche, N.; Abou Merhi, R. Anticancer Activities of Parthenolide in Primary Effusion Lymphoma Preclinical Models. Mol. Carcinog. 2021, 60, 567-581. [CrossRef] [PubMed]

114. Emanuele, S.; Oddo, E.; D'Anneo, A.; Notaro, A.; Calvaruso, G.; Lauricella, M.; Giuliano, M. Routes to Cell Death in Animal and Plant Kingdoms: From Classic Apoptosis to Alternative Ways to Die-A Review. Rend. Lincei. Sci. Fis. Nat. 2018, 29, 397-409. [CrossRef]

115. Pozarowski, P.; Halicka, D.H.; Darzynkiewicz, Z. Cell Cycle Effects and Caspase-Dependent and Independent Death of HL-60 and Jurkat Cells Treated with the Inhibitor of NF-KappaB Parthenolide. Cell Cycle 2003, 2, 377-383. [CrossRef] [PubMed]

116. D'Anneo, A.; Carlisi, D.; Lauricella, M.; Puleio, R.; Martinez, R.; Di Bella, S.; Di Marco, P.; Emanuele, S.; Di Fiore, R.; Guercio, A.; et al. Parthenolide Generates Reactive Oxygen Species and Autophagy in MDA-MB231 Cells. A Soluble Parthenolide Analogue Inhibits Tumour Growth and Metastasis in a Xenograft Model of Breast Cancer. Cell Death Dis. 2013, 4, e891. [CrossRef] [PubMed]

117. D’Anneo, A.; Carlisi, D.; Lauricella, M.; Emanuele, S.; Di Fiore, R.; Vento, R.; Tesoriere, G. Parthenolide Induces CaspaseIndependent and AIF-Mediated Cell Death in Human Osteosarcoma and Melanoma Cells. J. Cell. Physiol. 2013, $228,952-967$. [CrossRef]

118. Yao, H.; Tang, X.; Shao, X.; Feng, L.; Wu, N.; Yao, K. Parthenolide Protects Human Lens Epithelial Cells from Oxidative Stress-Induced Apoptosis via Inhibition of Activation of Caspase-3 and Caspase-9. Cell Res. 2007, 17, 565-571. [CrossRef]

119. Parzych, K.R.; Klionsky, D.J. An Overview of Autophagy: Morphology, Mechanism, and Regulation. Antioxid. Redox Signal. 2014, 20, 460-473. [CrossRef] 
120. Emanuele, S.; Lauricella, M.; D’Anneo, A.; Carlisi, D.; De Blasio, A.; Di Liberto, D.; Giuliano, M. P62: Friend or Foe? Evidences for OncoJanus and NeuroJanus Roles. Int. J. Mol. Sci. 2020, 21, 5029. [CrossRef]

121. Lei, Y.; Klionsky, D.J. The Emerging Roles of Autophagy in Human Diseases. Biomedicines 2021, 9, 1651. [CrossRef] [PubMed]

122. Kriel, J.; Loos, B. The Good, the Bad and the Autophagosome: Exploring Unanswered Questions of Autophagy-Dependent Cell Death. Cell Death Differ. 2019, 26, 640-652. [CrossRef] [PubMed]

123. Pellerito, C.; Emanuele, S.; Ferrante, F.; Celesia, A.; Giuliano, M.; Fiore, T. Tributyltin(IV) Ferulate, a Novel Synthetic Ferulic Acid Derivative, Induces Autophagic Cell Death in Colon Cancer Cells: From Chemical Synthesis to Biochemical Effects. J. Inorg. Biochem. 2020, 205, 110999. [CrossRef] [PubMed]

124. Kocaturk, N.M.; Akkoc, Y.; Kig, C.; Bayraktar, O.; Gozuacik, D.; Kutlu, O. Autophagy as a Molecular Target for Cancer Treatment. Eur. J. Pharm. Sci. 2019, 134, 116-137. [CrossRef]

125. Lan, B.; Wan, Y.-J.; Pan, S.; Wang, Y.; Yang, Y.; Leng, Q.-L.; Jia, H.; Liu, Y.; Zhang, C.-Z.; Cao, Y. Parthenolide Induces Autophagy via the Depletion of 4E-BP1. Biochem. Biophys. Res. Commun. 2015, 456, 434-439. [CrossRef]

126. Eramo, A.; Ricci-Vitiani, L.; Zeuner, A.; Pallini, R.; Lotti, F.; Sette, G.; Pilozzi, E.; Larocca, L.M.; Peschle, C.; De Maria, R. Chemotherapy Resistance of Glioblastoma Stem Cells. Cell Death Differ. 2006, 13, 1238-1241. [CrossRef]

127. Tang, T.K.; Chiu, S.C.; Lin, C.W.; Su, M.J.; Liao, M.H. Induction of survivin inhibition, $\mathrm{G}_{2} / \mathrm{M}$ cell cycle arrest and autophagic on cell death in human malignant glioblastoma cells. Chin. J. Physiol. 2015, 58, 95-103. [CrossRef]

128. Gào, X.; Schöttker, B. Reduction-Oxidation Pathways Involved in Cancer Development: A Systematic Review of Literature Reviews. Oncotarget 2017, 8, 51888-51906. [CrossRef]

129. Forman, H.J.; Zhang, H. Targeting Oxidative Stress in Disease: Promise and Limitations of Antioxidant Therapy. Nat. Rev. Drug Discov. 2021, 20, 689-709. [CrossRef]

130. Redza-Dutordoir, M.; Averill-Bates, D.A. Activation of Apoptosis Signalling Pathways by Reactive Oxygen Species. Biochim. Biophys. Acta (BBA)-Mol. Cell Res. 2016, 1863, 2977-2992. [CrossRef]

131. Yun, B.-R.; Lee, M.-J.; Kim, J.-H.; Kim, I.-H.; Yu, G.-R.; Kim, D.-G. Enhancement of Parthenolide-Induced Apoptosis by a PKC-Alpha Inhibition through Heme Oxygenase-1 Blockage in Cholangiocarcinoma Cells. Exp. Mol. Med. 2010, 42, 787-797. [CrossRef] [PubMed]

132. Duan, D.; Zhang, J.; Yao, J.; Liu, Y.; Fang, J. Targeting Thioredoxin Reductase by Parthenolide Contributes to Inducing Apoptosis of HeLa Cells. J. Biol. Chem. 2016, 291, 10021-10031. [CrossRef] [PubMed]

133. Wen, J.; You, K.-R.; Lee, S.-Y.; Song, C.-H.; Kim, D.-G. Oxidative Stress-Mediated Apoptosis: The anticancer effect of the sesquiterpene lactone parthenolide. J. Biol. Chem. 2002, 277, 38954-38964. [CrossRef]

134. Emanuele, S.; D'Anneo, A.; Calvaruso, G.; Cernigliaro, C.; Giuliano, M.; Lauricella, M. The Double-Edged Sword Profile of Redox Signaling: Oxidative Events as Molecular Switches in the Balance between Cell Physiology and Cancer. Chem. Res. Toxicol. 2018, 31, 201-210. [CrossRef] [PubMed]

135. Kim, S.-L.; Trang, K.T.T.; Kim, S.H.; Kim, I.H.; Lee, S.O.; Lee, S.T.; Kim, D.G.; Kim, S.-W. Parthenolide Suppresses Tumor Growth in a Xenograft Model of Colorectal Cancer Cells by Inducing Mitochondrial Dysfunction and Apoptosis. Int. J. Oncol. 2012, 41, 1547-1553. [CrossRef] [PubMed]

136. Kim, J.-H.; Liu, L.; Lee, S.-O.; Kim, Y.-T.; You, K.-R.; Kim, D.-G. Susceptibility of Cholangiocarcinoma Cells to Parthenolide-Induced Apoptosis. Cancer Res. 2005, 65, 6312-6320. [CrossRef] [PubMed]

137. Wang, W.; Adachi, M.; Kawamura, R.; Sakamoto, H.; Hayashi, T.; Ishida, T.; Imai, K.; Shinomura, Y. Parthenolide-Induced Apoptosis in Multiple Myeloma Cells Involves Reactive Oxygen Species Generation and Cell Sensitivity Depends on Catalase Activity. Apoptosis 2006, 11, 2225-2235. [CrossRef]

138. Flores-Lopez, G.; Moreno-Lorenzana, D.; Ayala-Sanchez, M.; Aviles-Vazquez, S.; Torres-Martinez, H.; Crooks, P.A.; Guzman, M.L.; Mayani, H.; Chávez-González, A. Parthenolide and DMAPT Induce Cell Death in Primitive CML Cells through Reactive Oxygen Species. J. Cell. Mol. Med. 2018, 22, 4899-4912. [CrossRef]

139. Sun, Y.; Clair, D.K.S.; Xu, Y.; Crooks, P.A.; Clair, W.H.S. A NADPH Oxidase-Dependent Redox Signaling Pathway Mediates the Selective Radiosensitization Effect of Parthenolide in Prostate Cancer Cells. Cancer Res. 2010, 70, 2880-2890. [CrossRef]

140. Carlisi, D.; D'Anneo, A.; Martinez, R.; Emanuele, S.; Buttitta, G.; Di Fiore, R.; Vento, R.; Tesoriere, G.; Lauricella, M. The Oxygen Radicals Involved in the Toxicity Induced by Parthenolide in MDA-MB-231 Cells. Oncol. Rep. 2014, 32, 167-172. [CrossRef]

141. D'Anneo, A.; Carlisi, D.; Emanuele, S.; Buttitta, G.; Di Fiore, R.; Vento, R.; Tesoriere, G.; Lauricella, M. Parthenolide Induces Superoxide Anion Production by Stimulating EGF Receptor in MDA-MB-231 Breast Cancer Cells. Int. J. Oncol. 2013, 43, 1895-1900. [CrossRef] [PubMed]

142. Kurdi, M.; Bowers, M.C.; Dado, J.; Booz, G.W. Parthenolide Induces a Distinct Pattern of Oxidative Stress in Cardiac Myocytes. Free Radic. Biol. Med. 2007, 42, 474-481. [CrossRef] [PubMed]

143. Dauer, P.; Sharma, N.S.; Gupta, V.K.; Nomura, A.; Dudeja, V.; Saluja, A.; Banerjee, S. GRP78-mediated Antioxidant Response and ABC Transporter Activity Confers Chemoresistance to Pancreatic Cancer Cells. Mol. Oncol. 2018, 12, 1498-1512. [CrossRef] [PubMed]

144. Chio, I.I.C.; Jafarnejad, S.M.; Ponz-Sarvise, M.; Park, Y.; Rivera, K.; Palm, W.; Wilson, J.; Sangar, V.; Hao, Y.; Öhlund, D.; et al NRF2 Promotes Tumor Maintenance by Modulating MRNA Translation in Pancreatic Cancer. Cell 2016, 166, 963-976. [CrossRef]

145. Emanuele, S.; Celesia, A.; D'Anneo, A.; Lauricella, M.; Carlisi, D.; De Blasio, A.; Giuliano, M. The Good and Bad of Nrf2: An Update in Cancer and New Perspectives in COVID-19. Int. J. Mol. Sci. 2021, 22, 7963. [CrossRef] 
146. Carlisi, D.; De Blasio, A.; Drago-Ferrante, R.; Di Fiore, R.; Buttitta, G.; Morreale, M.; Scerri, C.; Vento, R.; Tesoriere, G. Parthenolide Prevents Resistance of MDA-MB231 Cells to Doxorubicin and Mitoxantrone: The Role of Nrf2. Cell Death Discov. 2017, 3, 17078. [CrossRef]

147. De Blasio, A.; Di Fiore, R.; Pratelli, G.; Drago-Ferrante, R.; Saliba, C.; Baldacchino, S.; Grech, G.; Scerri, C.; Vento, R.; Tesoriere, G. A Loop Involving NRF2, MiR-29b-1-5p and AKT, Regulates Cell Fate of MDA-MB-231 Triple-Negative Breast Cancer Cells. J. Cell. Physiol. 2020, 235, 629-637. [CrossRef]

148. Drago-Ferrante, R.; Pentimalli, F.; Carlisi, D.; Blasio, A.D.; Saliba, C.; Baldacchino, S.; Degaetano, J.; Debono, J.; Caruana-Dingli, G.; Grech, G.; et al. Suppressive Role Exerted by MicroRNA-29b-1-5p in Triple Negative Breast Cancer through SPIN1 Regulation. Oncotarget 2017, 8, 28939-28958. [CrossRef]

149. Pei, S.; Minhajuddin, M.; D’Alessandro, A.; Nemkov, T.; Stevens, B.M.; Adane, B.; Khan, N.; Hagen, F.K.; Yadav, V.K.; De, S.; et al. Rational Design of a Parthenolide-Based Drug Regimen That Selectively Eradicates Acute Myelogenous Leukemia Stem Cells. J. Biol. Chem. 2016, 291, 21984-22000. [CrossRef]

150. Carlisi, D.; Buttitta, G.; Di Fiore, R.; Scerri, C.; Drago-Ferrante, R.; Vento, R.; Tesoriere, G. Parthenolide and DMAPT Exert Cytotoxic Effects on Breast Cancer Stem-like Cells by Inducing Oxidative Stress, Mitochondrial Dysfunction and Necrosis. Cell Death Dis. 2016, 7, e2194. [CrossRef]

151. Mendonca, M.S.; Turchan, W.T.; Alpuche, M.E.; Watson, C.N.; Estabrook, N.C.; Chin-Sinex, H.; Shapiro, J.B.; Imasuen-Williams, I.E.; Rangel, G.; Gilley, D.P.; et al. DMAPT Inhibits NF-кB Activity and Increases Sensitivity of Prostate Cancer Cells to X-Rays In Vitro and in Tumor Xenografts In Vivo. Free Radic. Biol. Med. 2017, 112, 318-326. [CrossRef] [PubMed]

152. Oka, D.; Nishimura, K.; Shiba, M.; Nakai, Y.; Arai, Y.; Nakayama, M.; Takayama, H.; Inoue, H.; Okuyama, A.; Nonomura, N Sesquiterpene Lactone Parthenolide Suppresses Tumor Growth in a Xenograft Model of Renal Cell Carcinoma by Inhibiting the Activation of NF-kB. Int. J. Cancer 2007, 120, 2576-2581. [CrossRef] [PubMed]

153. Sweeney, C.J.; Mehrotra, S.; Sadaria, M.R.; Kumar, S.; Shortle, N.H.; Roman, Y.; Sheridan, C.; Campbell, R.A.; Murry, D.J.; Badve, S.; et al. The Sesquiterpene Lactone Parthenolide in Combination with Docetaxel Reduces Metastasis and Improves Survival in a Xenograft Model of Breast Cancer. Mol. Cancer 2005, 4, 1004-1012. [CrossRef] [PubMed]

154. Curry, E.A.; Murry, D.J.; Yoder, C.; Fife, K.; Armstrong, V.; Nakshatri, H.; O'Connell, M.; Sweeney, C.J. Phase I Dose Escalation Trial of Feverfew with Standardized Doses of Parthenolide in Patients with Cancer. Investig. New Drugs 2004, 22, 299-305. [CrossRef]

155. Wan Kamarul Zaman, W.S.; Nurul, A.A.; Nordin, F. Stem Cells and Cancer Stem Cells: The Jekyll and Hyde Scenario and Their Implications in Stem Cell Therapy. Biomedicines 2021, 9, 1245. [CrossRef]

156. Walcher, L.; Kistenmacher, A.-K.; Suo, H.; Kitte, R.; Dluczek, S.; Strauß, A.; Blaudszun, A.-R.; Yevsa, T.; Fricke, S.; Kossatz-Boehlert, U. Cancer Stem Cells_-Origins and Biomarkers: Perspectives for Targeted Personalized Therapies. Front. Immunol. 2020, 11, 1280. [CrossRef]

157. Kuşoğlu, A.; Biray Avc1, Ç. Cancer Stem Cells: A Brief Review of the Current Status. Gene 2019, 681, 80-85. [CrossRef]

158. Zhang, S.; Ju, X.; Yang, Q.; Zhu, Y.; Fan, D.; Su, G.; Kong, L.; Li, Y. USP47 maintains the stemness of colorectal cancer cells and is inhibited by parthenolide. Biochem. Biophys. Res. Commun. 2021, 562, 21-28. [CrossRef]

159. Dandawate, P.R.; Subramaniam, D.; Jensen, R.A.; Anant, S. Targeting Cancer Stem Cells and Signaling Pathways by Phytochemicals: Novel Approach for Breast Cancer Therapy. Semin. Cancer Biol. 2016, 40-41, 192-208. [CrossRef]

160. Nguyen, N.P.; Almeida, F.S.; Chi, A.; Nguyen, L.M.; Cohen, D.; Karlsson, U.; Vinh-Hung, V. Molecular biology of breast cancer stem cells: Potential clinical applications. Cancer Treat. Rev. 2010, 36, 485-491. [CrossRef]

161. Yi, J.; Wang, L.; Wang, X.-Y.; Sun, J.; Yin, X.-Y.; Hou, J.-X.; Chen, J.; Xie, B.; Wei, H.-L. Suppression Of Aberrant Activation Of NF-кB Pathway in Drug-Resistant Leukemia Stem Cells Contributes To Parthenolide-Potentiated Reversal Of Drug Resistance in Leukemia. J. Cancer 2021, 12, 5519-5529. [CrossRef] [PubMed]

162. Gunn, E.J.; Williams, J.T.; Huynh, D.T.; Iannotti, M.J.; Han, C.; Barrios, F.J.; Kendall, S.; Glackin, C.A.; Colby, D.A.; Kirshner, J The Natural Products Parthenolide and Andrographolide Exhibit Anti-Cancer Stem Cell Activity in Multiple Myeloma. Leuk. Lymphoma 2011, 52, 1085-1097. [CrossRef] [PubMed]

163. Zhou, J.; Zhang, H.; Gu, P.; Bai, J.; Margolick, J.B.; Zhang, Y. NF-kB Pathway Inhibitors Preferentially Inhibit Breast Cancer Stem-like Cells. Breast Cancer Res. Treat 2008, 111, 419-427. [CrossRef] [PubMed]

164. Liu, Y.; Lu, W.-L.; Guo, J.; Du, J.; Li, T.; Wu, J.-W.; Wang, G.-L.; Wang, J.-C.; Zhang, X.; Zhang, Q. A Potential Target Associated with Both Cancer and Cancer Stem Cells: A Combination Therapy for Eradication of Breast Cancer Using Vinorelbine Stealthy Liposomes plus Parthenolide Stealthy Liposomes. J. Control. Release 2008, 129, 18-25. [CrossRef] [PubMed]

165. Abdullah, L.N.; Chow, E.K.-H. Mechanisms of Chemoresistance in Cancer Stem Cells. Clin. Transl. Med. 2013, 2, 3. [CrossRef]

166. Liao, K.; Xia, B.; Zhuang, Q.-Y.; Hou, M.-J.; Zhang, Y.-J.; Luo, B.; Qiu, Y.; Gao, Y.-F.; Li, X.-J.; Chen, H.-F.; et al. Parthenolide Inhibits Cancer Stem-Like Side Population of Nasopharyngeal Carcinoma Cells via Suppression of the NF- $\mathrm{kB} / \mathrm{COX}-2$ Pathway. Theranostics 2015, 5, 302-321. [CrossRef]

167. Zhang, D.; Qiu, L.; Jin, X.; Guo, Z.; Guo, C. Nuclear Factor-KB Inhibition by Parthenolide Potentiates the Efficacy of Taxol in Non-Small Cell Lung Cancer In Vitro and In Vivo. Mol. Cancer Res. 2009, 7, 1139-1149. [CrossRef]

168. Shanmugam, R.; Jayaprakasan, V.; Gokmen-Polar, Y.; Kelich, S.; Miller, K.D.; Yip-Schneider, M.; Cheng, L.; Bhat-Nakshatri, P.; Sledge, G.W., Jr.; Nakshatri, H.; et al. Restoring Chemotherapy and Hormone Therapy Sensitivity by Parthenolide in a Xenograft Hormone Refractory Prostate Cancer Model. Prostate 2006, 66, 1498-1511. [CrossRef] 
169. deGraffenried, L.A.; Chandrasekar, B.; Friedrichs, W.E.; Donzis, E.; Silva, J.; Hidalgo, M.; Freeman, J.W.; Weiss, G.R. NF-kB Inhibition Markedly Enhances Sensitivity of Resistant Breast Cancer Tumor Cells to Tamoxifen. Ann. Oncol. 2004, 15, 885-890. [CrossRef]

170. Riggins, R.B.; Zwart, A.; Nehra, R.; Clarke, R. The Nuclear Factor KB Inhibitor Parthenolide Restores ICI 182,780 (Faslodex; Fulvestrant)-Induced Apoptosis in Antiestrogen-Resistant Breast Cancer Cells. Mol. Cancer 2005, 4, $33-41$.

171. Carlisi, D.; Lauricella, M.; D’Anneo, A.; Buttitta, G.; Emanuele, S.; di Fiore, R.; Martinez, R.; Rolfo, C.; Vento, R.; Tesoriere, G. The Synergistic Effect of SAHA and Parthenolide in MDA-MB231 Breast Cancer Cells. J. Cell. Physiol. 2015, 230, 1276-1289. [CrossRef] [PubMed]

172. Fang, L.-J.; Shao, X.-T.; Wang, S.; Lu, G.-H.; Xu, T.; Zhou, J.-Y. Sesquiterpene Lactone Parthenolide Markedly Enhances Sensitivity of Human A549 Cells to Low-Dose Oxaliplatin via Inhibition of NF-kB Activation and Induction of Apoptosis. Planta Med. 2010, 76, 258-264. [CrossRef] [PubMed]

173. Francescato, H.D.C.; Costa, R.S.; Scavone, C.; Coimbra, T.M. Parthenolide Reduces Cisplatin-Induced Renal Damage. Toxicology 2007, 230, 64-75. [CrossRef]

174. Ghorbani-Abdi-Saedabad, A.; Hanafi-Bojd, M.Y.; Parsamanesh, N.; Tayarani-Najaran, Z.; Mollaei, H.; Hoshyar, R. Anticancer and Apoptotic Activities of Parthenolide in Combination with Epirubicin in Mda-Mb-468 Breast Cancer Cells. Mol. Biol Rep. 2020, 47, 5807-5815. [CrossRef]

175. Ralstin, M.C.; Gage, E.A.; Yip-Schneider, M.T.; Klein, P.J.; Wiebke, E.A.; Schmidt, C.M. Parthenolide Cooperates with NS398 to Inhibit Growth of Human Hepatocellular Carcinoma Cells through Effects on Apoptosis and G0-G1 Cell Cycle Arrest. Mol. Cancer Res. 2006, 4, 387-399. [CrossRef] [PubMed]

176. Yip-Schneider, M.T.; Wu, H.; Ralstin, M.; Yiannoutsos, C.; Crooks, P.A.; Neelakantan, S.; Noble, S.; Nakshatri, H.; Sweeney, C.J.; Schmidt, C.M. Suppression of Pancreatic Tumor Growth by Combination Chemotherapy with Sulindac and LC-1 Is Associated with Cyclin D1 Inhibition in Vivo. Mol. Cancer 2007, 6, 1736-1744. [CrossRef] [PubMed]

177. Taguchi, T.; Takao, T.; Iwasaki, Y.; Nishiyama, M.; Asaba, K.; Hashimoto, K. Suppressive Effects of Dehydroepiandrosterone and the Nuclear Factor-KB Inhibitor Parthenolide on Corticotroph Tumor Cell Growth and Function In Vitro and In Vivo. J. Endocrinol. 2006, 188, 321-331. [CrossRef]

178. Duechler, M.; Stańczyk, M.; Czyż, M.; Stępnik, M. Potentiation of Arsenic Trioxide Cytotoxicity by Parthenolide and Buthionine Sulfoximine in Murine and Human Leukemic Cells. Cancer Chemother. Pharm. 2008, 61, 727-737. [CrossRef]

179. Watson, C.; Miller, D.A.; Chin-Sinex, H.; Losch, A.; Hughes, W.; Sweeney, C.; Mendonca, M.S. Suppression of NF-kB Activity by Parthenolide Induces X-Ray Sensitivity through Inhibition of Split-Dose Repair in TP53 Null Prostate Cancer Cells. Radiat. Res. 2009, 171, 389-396. [CrossRef]

180. Hayashi, S.; Hatashita, M.; Hayashi, A.; Matsumoto, H.; Shioura, H.; Kitai, R. Thermosensitization by Parthenolide in Human Lung Adenocarcinoma A549 Cells and P53- and Hsp72-Independent Apoptosis Induction via the Nuclear Factor-KB Signal Pathway. Int. J. Mol. Med. 2008, 21, 585-592. [CrossRef]

181. Hayashi, S.; Sakurai, H.; Hayashi, A.; Tanaka, Y.; Hatashita, M.; Shioura, H. Inhibition of NF-кB by Combination Therapy with Parthenolide and Hyperthermia and Kinetics of Apoptosis Induction and Cell Cycle Arrest in Human Lung Adenocarcinoma Cells. Int. J. Mol. Med. 2010, 25, 81-87. [CrossRef] [PubMed]

182. Jia, X.; Liu, Q.; Wang, S.; Zeng, B.; Du, G.; Zhang, C.; Li, Y. Synthesis, Cytotoxicity, and in Vivo Antitumor Activity Study of Parthenolide Semicarbazones and Thiosemicarbazones. Bioorg. Med. Chem. 2020, 28, 115557. [CrossRef] [PubMed]

183. Karmakar, A.; Xu, Y.; Mustafa, T.; Kannarpady, G.; Bratton, S.M.; Radominska-Pandya, A.; Crooks, P.A.; Biris, A.S. Nanodelivery of Parthenolide Using Functionalized Nanographene Enhances Its Anticancer Activity. RSC Adv. 2015, 5, 2411-2420. [CrossRef] [PubMed]

184. Darwish, N.H.E.; Sudha, T.; Godugu, K.; Bharali, D.J.; Elbaz, O.; El-ghaffar, H.A.A.; Azmy, E.; Anber, N.; Mousa, S.A. Novel Targeted Nano-Parthenolide Molecule against NF-кB in Acute Myeloid Leukemia. Molecules 2019, 24, 2103. [CrossRef]

185. Zhai, J.-D.; Li, D.; Long, J.; Zhang, H.-L.; Lin, J.-P.; Qiu, C.-J.; Zhang, Q.; Chen, Y. Biomimetic Semisynthesis of Arglabin from Parthenolide. J. Org. Chem. 2012, 77, 7103-7107. [CrossRef]

186. Lone, S.H.; Bhat, K.A.; Khuroo, M.A. Arglabin: From Isolation to Antitumor Evaluation. Chem.-Biol. Interact. 2015, 240, 180-198. [CrossRef]

187. Zhang, Q.; Lu, Y.; Ding, Y.; Zhai, J.; Ji, Q.; Ma, W.; Yang, M.; Fan, H.; Long, J.; Tong, Z.; et al. Guaianolide Sesquiterpene Lactones, a Source to Discover Agents That Selectively Inhibit Acute Myelogenous Leukemia Stem and Progenitor Cells. J. Med. Chem. 2012, 55, 8757-8769. [CrossRef]

188. He, W.; Lai, R.; Lin, Q.; Huang, Y.; Wang, L. Arglabin is a plant sesquiterpene lactone that exerts potent anticancer effects on human oral squamous cancer cells via mitochondrial apoptosis and downregulation of the mTOR/PI3K/Akt signaling pathway to inhibit tumor growth in vivo. J. Buon 2018, 23, 1679-1685.

189. Yu, L.; Chen, W.; Tang, Q.; Ji, K.-Y. Micheliolide Inhibits Liver Cancer Cell Growth Via Inducing Apoptosis And Perturbing Actin Cytoskeleton. Cancer Manag. Res. 2019, 11, 9203-9212. [CrossRef]

190. Viennois, E.; Xiao, B.; Ayyadurai, S.; Wang, L.; Wang, P.G.; Zhang, Q.; Chen, Y.; Merlin, D. Micheliolide, a New Sesquiterpene Lactone That Inhibits Intestinal Inflammation and Colitis-Associated Cancer. Lab. Investig. 2014, 94, 950-965. [CrossRef] 
191. Zhong, J.; Gong, W.; Chen, J.; Qing, Y.; Wu, S.; Li, H.; Huang, C.; Chen, Y.; Wang, Y.; Xu, Z.; et al. Micheliolide Alleviates Hepatic Steatosis in $\mathrm{Db} / \mathrm{Db}$ Mice by Inhibiting Inflammation and Promoting Autophagy via PPAR- $\gamma$-Mediated NF-KB and AMPK/MTOR Signaling. Int. Immunopharmacol. 2018, 59, 197-208. [CrossRef] [PubMed]

192. Tang, X.; Ding, Q.; Chen, C.; Chen, F.; Zhou, X.; Hong, C.J.; Pan, W. Micheliolide Inhibits Gastric Cancer Growth in Vitro and in Vivo via Blockade of the IL-6/STAT3 Pathway. Die Pharm. Int. J. Pharm. Sci. 2019, 74, 175-178. [CrossRef]

193. Li, J.; Li, S.; Guo, J.; Li, Q.; Long, J.; Ma, C.; Ding, Y.; Yan, C.; Li, L.; Wu, Z.; et al. Natural Product Micheliolide (MCL) Irreversibly Activates Pyruvate Kinase M2 and Suppresses Leukemia. J. Med. Chem. 2018, 61, 4155-4164. [CrossRef] [PubMed]

194. An, Y.; Guo, W.; Li, L.; Xu, C.; Yang, D.; Wang, S.; Lu, Y.; Zhang, Q.; Zhai, J.; Fan, H.; et al. Micheliolide Derivative DMAMCL Inhibits Glioma Cell Growth In Vitro and In Vivo. PLoS ONE 2015, 10, e0116202. [CrossRef]

195. Liu, Y.; Wang, L.; Liu, J.; Xie, X.; Hu, H.; Luo, F. Anticancer Effects of ACT001 via NF-кB Suppression in Murine Triple-Negative Breast Cancer Cell Line 4T1. Cancer Manag. Res. 2020, 12, 5131-5139. [CrossRef]

196. Jin, X.-H.; Jia, Y.-S.; Shi, Y.-H.; Li, Q.-Y.; Bao, S.-Q.; Lu, W.-P.; Tong, Z.-S. ACT001 Can Prevent and Reverse Tamoxifen Resistance in Human Breast Cancer Cell Lines by Inhibiting NF-кB Activation. J. Cell. Biochem. 2019, 120, 1386-1397. [CrossRef]

197. Hou, Y.; Sun, B.; Liu, W.; Yu, B.; Shi, Q.; Luo, F.; Bai, Y.; Feng, H. Targeting of Glioma Stem-like Cells with a Parthenolide Derivative ACT001 through Inhibition of AEBP1/PI3K/AKT Signaling. Theranostics 2021, 11, 555-566. [CrossRef] 